بازتاب واقعه عاثورا و قيام امام حسين(ع) در اشعار فارسى: از قدرت يابى صفويه تا دوران معاصر

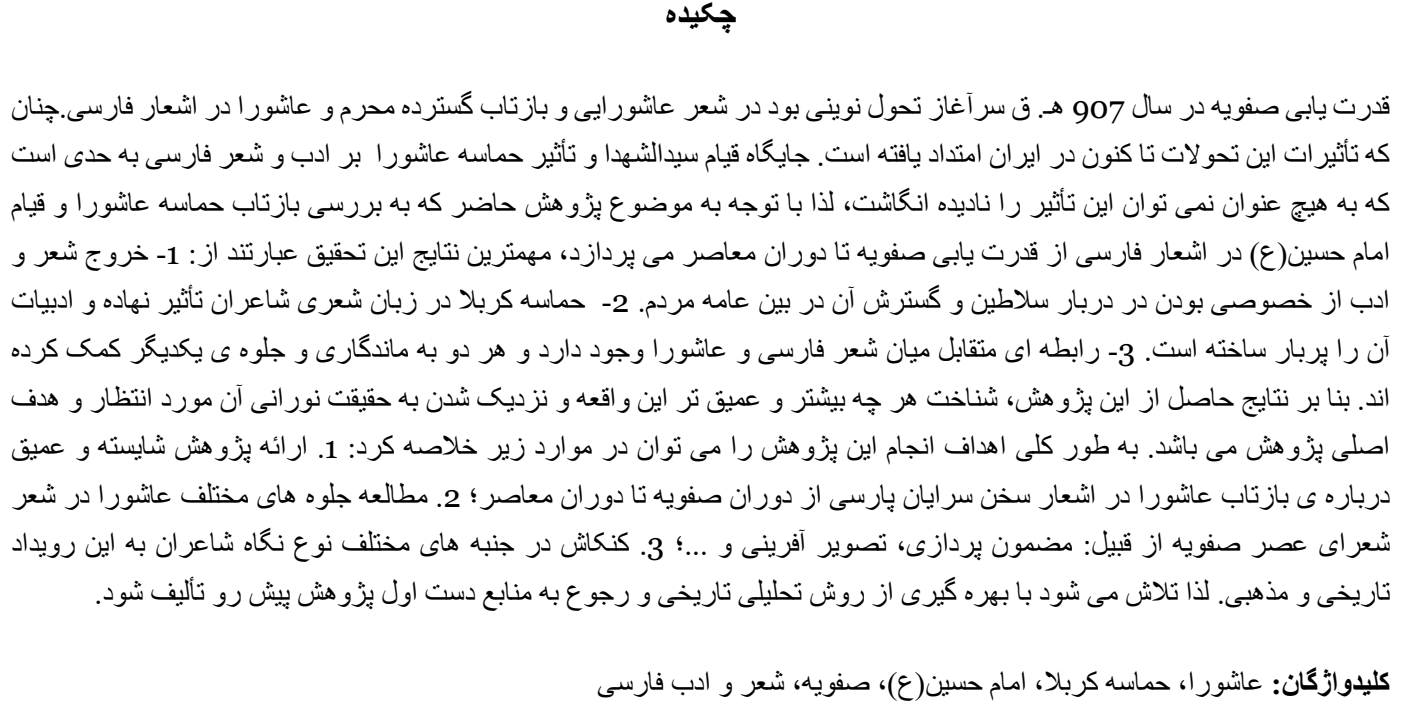

\title{
Âşûrâ Vak'ası ve Hz. Hüseyin'in (as) kıyamının Fars şiirine etkisi: Safevî’den günümüze
}

\section{Ahmet YEŞIL' ${ }^{1}$}

APA: Yeşil, A. (2019). Âşûrâ Vak'ası ve Hz. Hüseyin'in (as) kıyamının Fars şiirine etkisi: Safevî’den günümüze. RumeliDE Dil ve Edebiyat Araştırmaları Dergisi, (16), 677-692. DOI: 10.29000/rumelide.619690

\section{$\ddot{\mathbf{O} z}$}

Safevilerin güç kazanmasıyla birlikte (1501-1736), Fars şiirinde Muharrem ve Âşûrâ'nın etkisi yoğun bir şekilde hissedilmeye başlamış ve Âşûrâ şiirinde bir dönüşümün meydana gelmiştir ki, bu dönüşümün etkisi halan İran şiirinde gözlemlenmektedir. Hz Hüseyin Kıyamı ve Âşûrâ vakıasının Farsça şiirler üzerindeki etkisi, hiçbir şekilde göz ardı edilemeyecek bir düzeyde olmuştur. Âşûrâ vakıası ve İmam Hüseyin'in (as) Safevî’den günümüze kadar kaleme alınan Farsça şiirlere etkisinin araştırıldığı bu makalede elde edilen bulgulara göre: 1- Saray ve çevresine ait olarak görülen Şiir ve edebiyat halk arasına yayılmıştır; 2. Kerbelâ vakası, Fars şairlerin dilini etkilemiş ve ortaya koydukları eserlerin zenginleşmesini sağlamışır; 3. Farsça şiirler ile Âşûrâ kıyamı arasında karşılıklı bir ilişki vardır; ikisi de bir diğerinin güncelliğinin korunasında rol oynamıştır. Bu çalışmanın sonuçlarına göre, bu olayın daha fazla tanınması ve bu olgunun daha da aydınlatılması araştırmanın asıl amacıdır. Genel olarak, bu araştırmanın amaçları şu şekilde özetlenebilir: 1. Âşûrâ'nın Fars şairlerin şiirlerine yansıyışını Safevî döneminden günümüze kadar incelenmesi; 2. Âşûrâ'nin çeşitli yönlerinin Safevi dönemi şiirinde tema, hayal gücü vs. bakımından incelenmesi; 3. Bu tarihi ve dini olayda şairlerin bakış açısının farklı yönlerden incelenmesi. Bu nedenle, çalışmada tarihsel analitik yöntemi kullanılmış ve bu araştırmanın gerçekleştirilmesinde birincil kaynaklar kullanılmaya çalışılmıştır.

1 Dr. Öğr. Üyesi, Sakarya Üniversitesi, İlahiyat Fakültesi, İslam Tarihi ve Sanatları, Türk İslam Edebiyatı ABD (Sakarya, Türkiye), ahmetyesil@sakarya.edu.tr, ORCID ID: 00oo-0002-0606-5177 [Makale kayıt tarihi: 09.08.2019-kabul tarihi: 20.09.2019; DOI: 10.29000/rumelide.619690] 
Reflection of the event of Ashura and the uprising of Imam Hossein (AS) in Persian poems from the power of Safavid until contemporary periods / A. Yeşil (p. 677-692)

Anahtar kelimeler: Âşûrâ, Kerbelâ destanı, İmam Hüseyin, Safevi, Fars şiiri ve edebiyatı.

\title{
Reflection of the event of Ashura and the uprising of Imam Hossein (AS) in Persian poems from the power of Safavid until contemporary periods
}

\begin{abstract}
The power of the Safavid in $907 \mathrm{AH}$ was the beginning of a new transformation in Ashura's poem and the extensive reflection of Muharram and Ashura in Persian poems, as the effects of these developments have so far lasted in Iran. The position of the uprising of Seyyed Al-Shohada and the effect of the Ashura's epic on Persian poem is such that it cannot be ignored in any way. According to the present research that investigates the reflection of the epic of Ashura and the uprising of Imam Hossein (AS) in poems from the Safavid power to the contemporary periods, the most important results of this research are: 1- Exit of poem and literature from being private at the court of the Sultans and spreading it among the general public. 2. Karbala's epic influences poetry language of poets and its literature has been influenced. 3. There is a reciprocal relationship between Persian poem and Ashura, and both have contributed to the survival of each other. According to the results of this study, the more recognition of this event and its approach to its light truth is expected and the main goal of the research. In general, the goals of this research can be summarized as follows: 1 . To provide a competent and profound study about the reflection of Ashura in the poems of Persian poets from the Safavid period to contemporary; 2. Study of the various aspects of Ashura in poem of the Safavid age such as: theme, imagination and ... 3. Investigating the different aspects of the kind of poets view at this historical and religious event. Therefore, it is attempted to use the historical analytical method and refer to the first sources of the research to be written this research.
\end{abstract}

Keywords: Ashura, Karbala epic, Imam Hossein (AS), Safavid, Persian poem and literature.

\section{مقدمه}

بر اساس آموزه هاى فرهنى تشيع حماسه ى عاشور ا نقطه كمال و جُكيده كوشش و جهاد تمام انبياء و اولياء خداوند در طول تاريخ

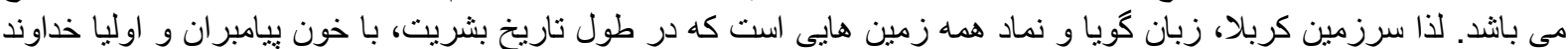

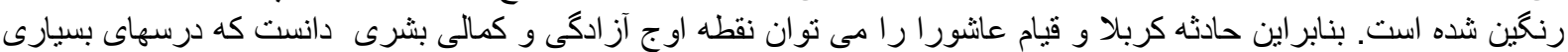

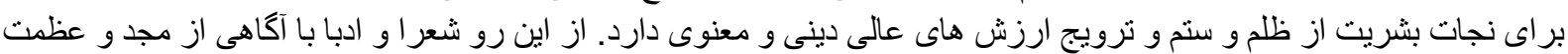

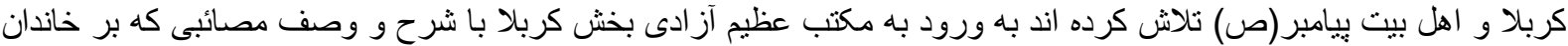

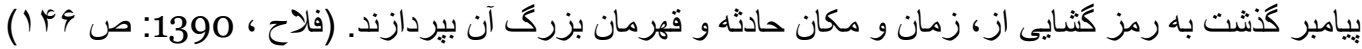

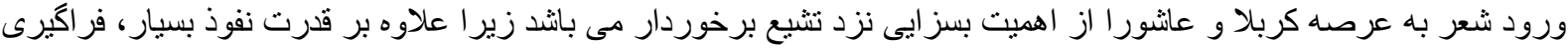

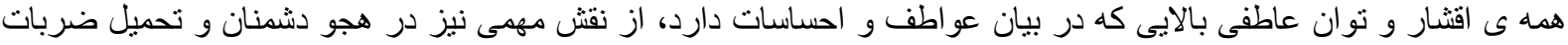

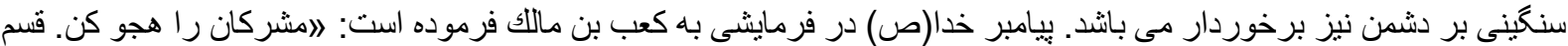

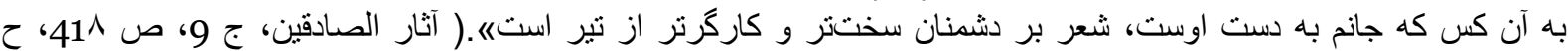

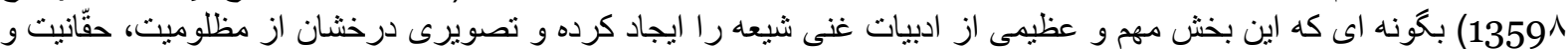

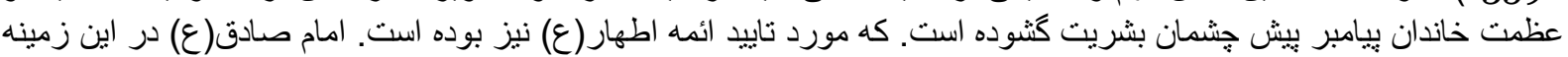

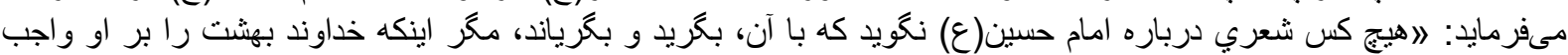

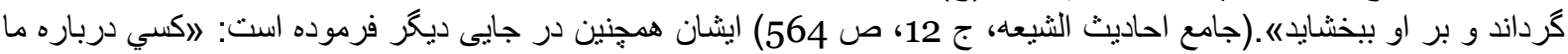

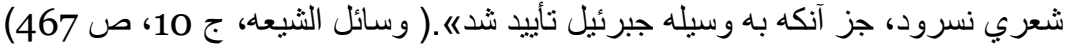

در بررسى تاريخى مرثيه سرايى فارسى قرون ششم نا هشتم را مى نوان دوران تجربه هاى نو در سرودن مرثيه هاى مذهبى

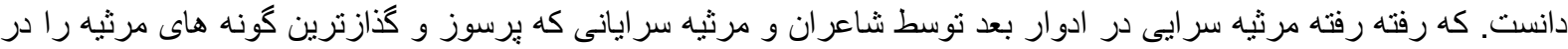

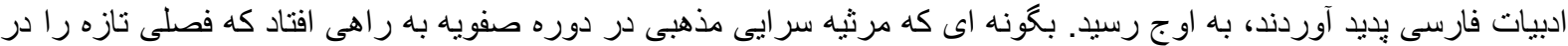


شعر فارسى كثود. از آن تاريخ تاكنون صدها شاعر با شور و شيدايى خاصى هزاران بيت شعر در وصف رئ حماسه كربلا و قهرمانان

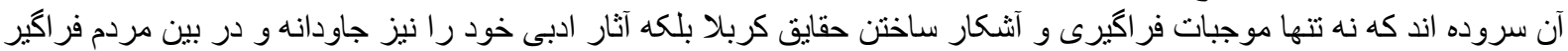

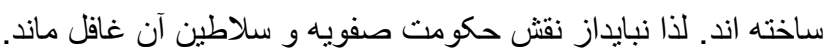

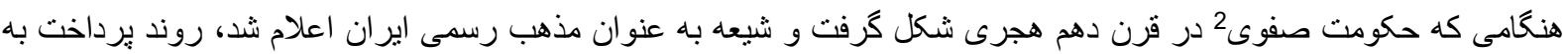

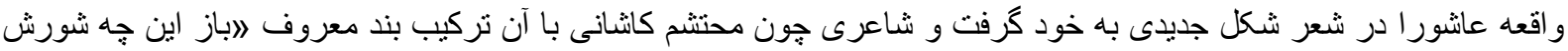

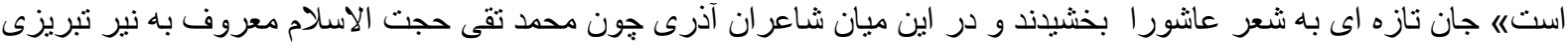

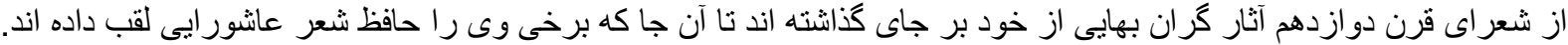

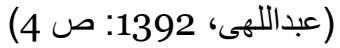

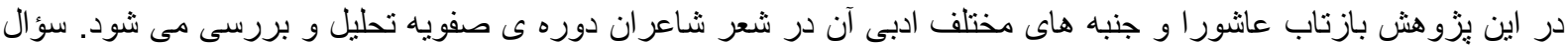

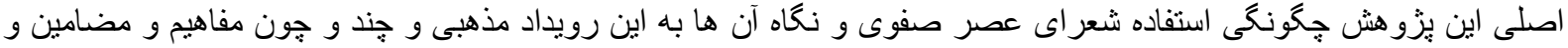

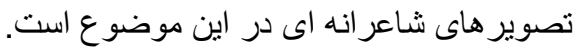

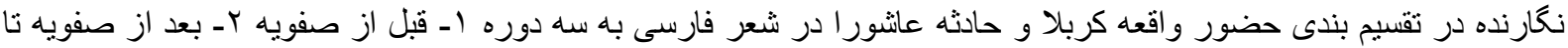

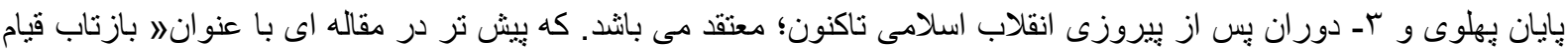

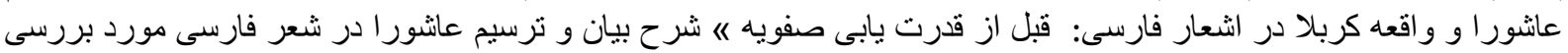

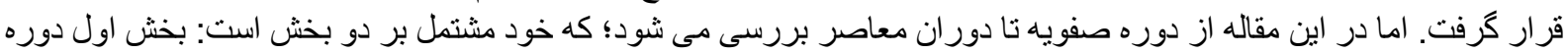

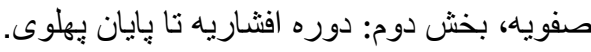

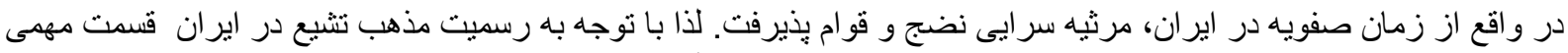

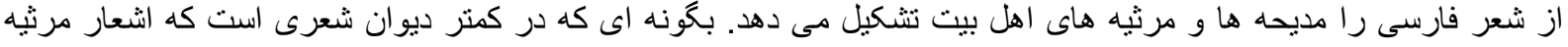

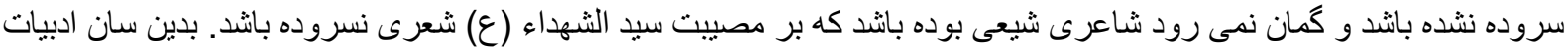

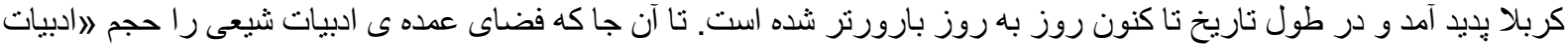
طف «3 بِر كرده است.

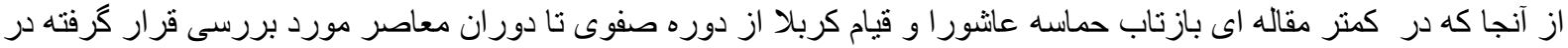

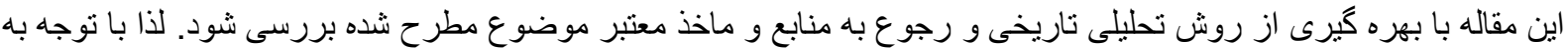

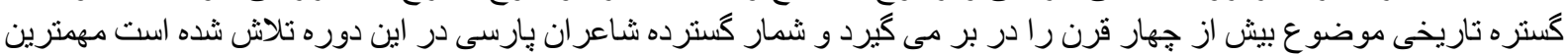

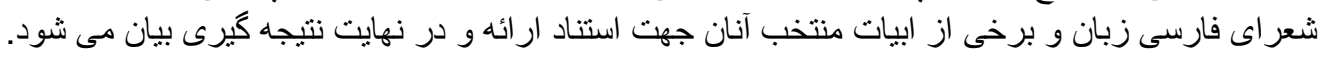

\section{دوره صفويه}

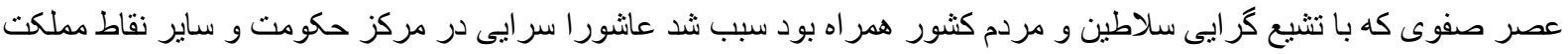

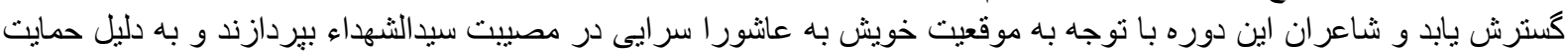

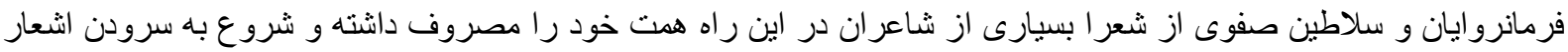

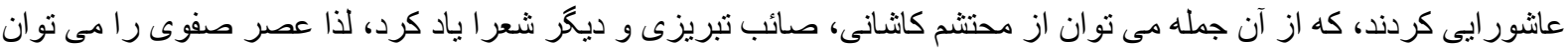

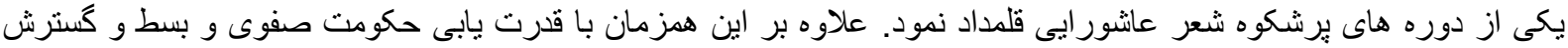

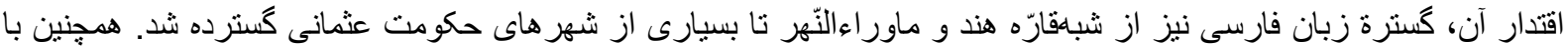

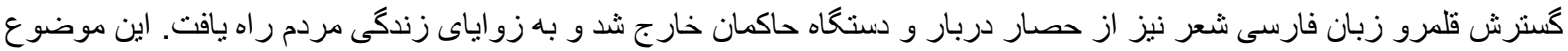

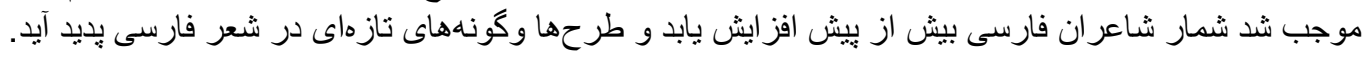

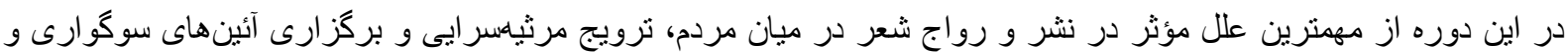

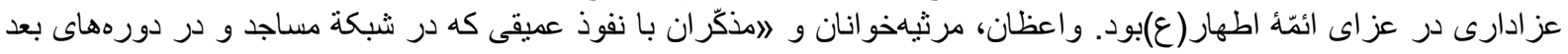

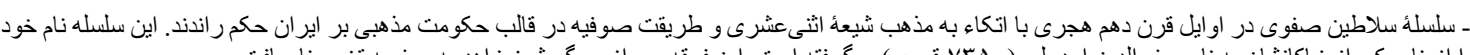

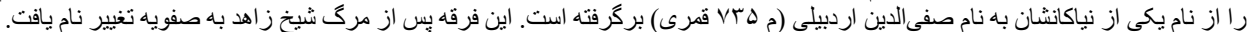

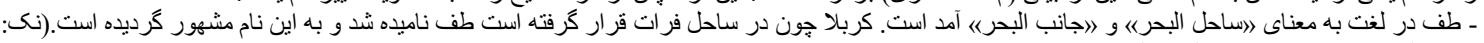

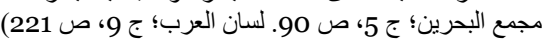




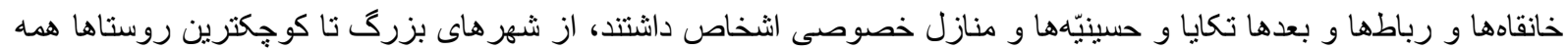

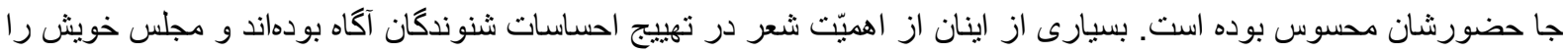

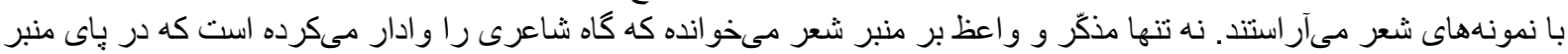

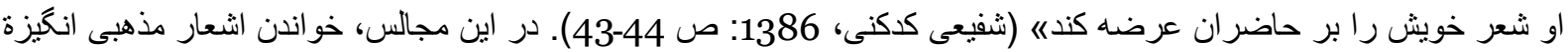

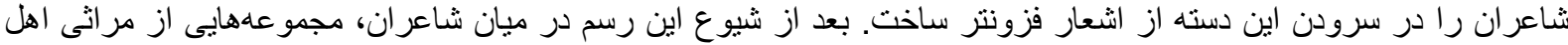

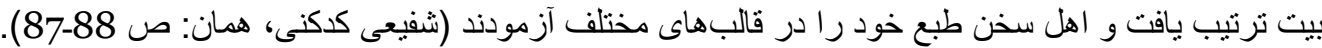

شاعر ان اين دوره در قالب هابي متعدد از جمله قصيده و تركيب بند كه مهم ترين آنها هستتد به مرثيه و مدح آن امام شعيد برداختهاند

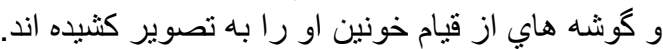

از سرشناس ترين شعر اى اين عصر كه در قالب تركيب بند در رثاى امام حسين و قيام عاثشور اشعر سروده است محتشم كاثشانى

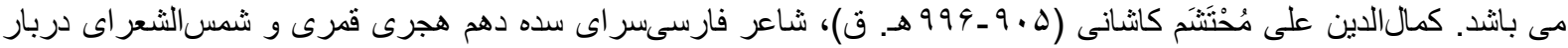

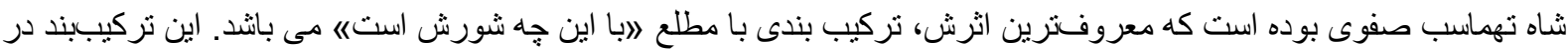

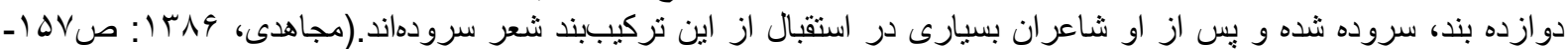

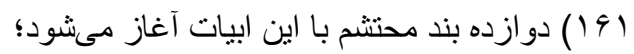

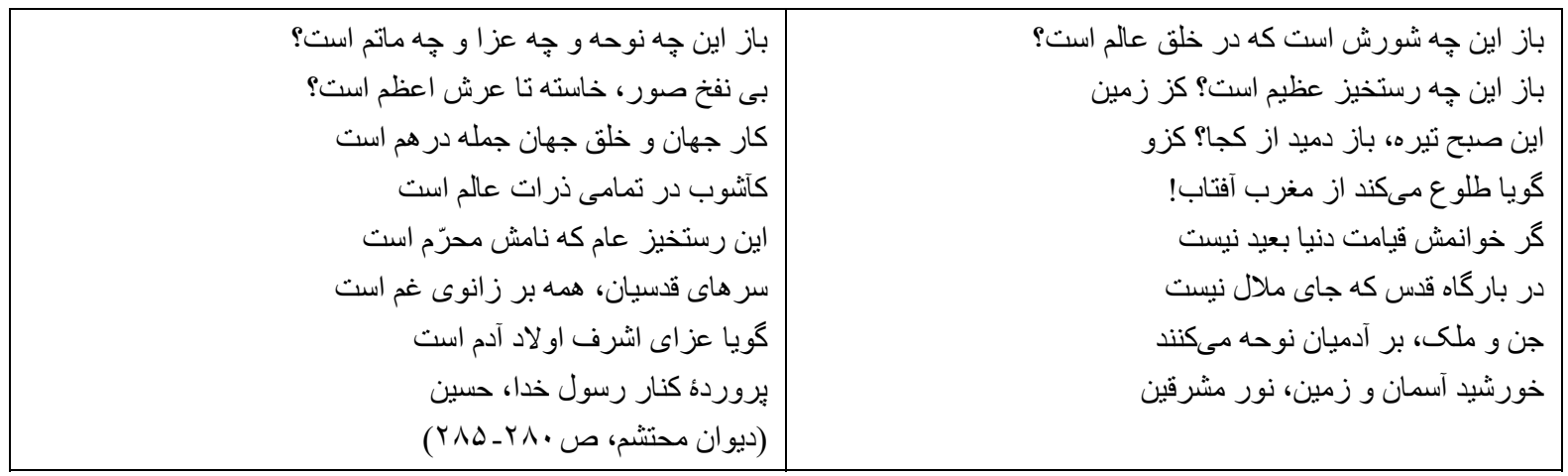

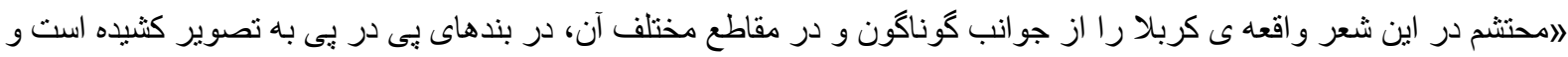

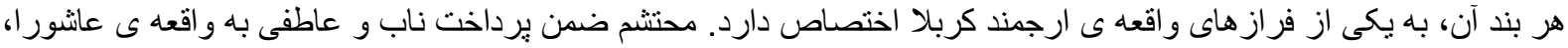

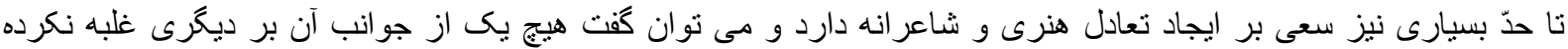

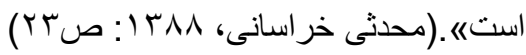

در ديوان محتشم علاوه بر تركيب بند او ، قصيدهاى در مرثيه امام حسين (ع) وجود دارد كه با اين بيت مشروع مى شود:

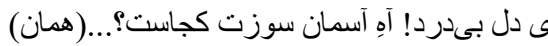
اين زمين بربلا را نام دشت كربلاست

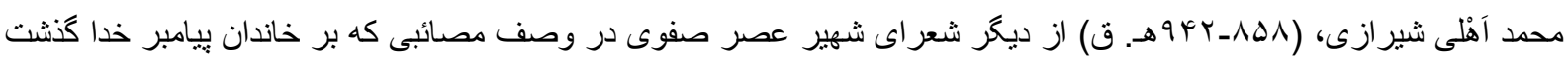

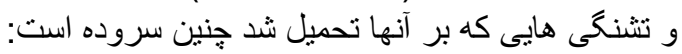

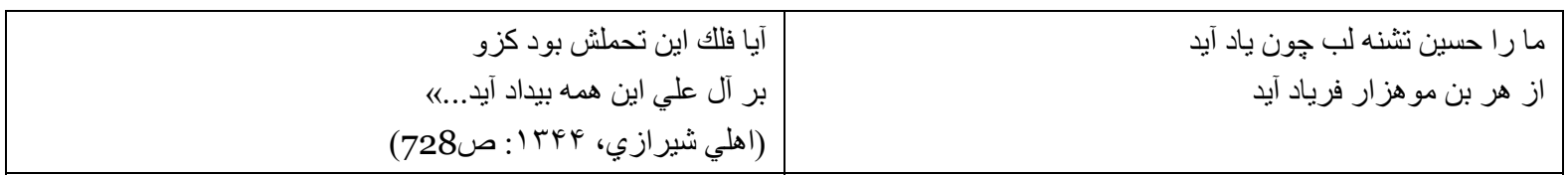

وى همجنين در جايى ديكر سروده است:

\begin{tabular}{|c|c|}
\hline 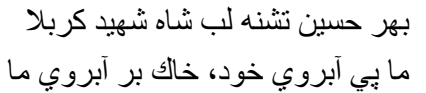 & 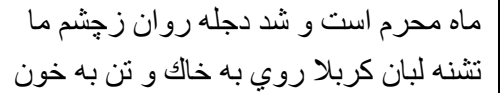 \\
\hline
\end{tabular}


اهلى شير ازى، علاوه بر هفت قصيده اى كه در رثاى كربلا و قيام عاشورا دارد، جند تركيبند در منقبت بِيامبر(ص)، حضرت

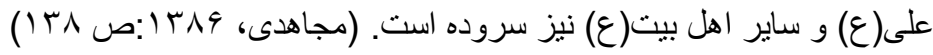

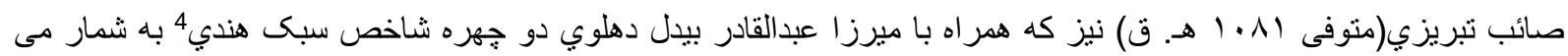

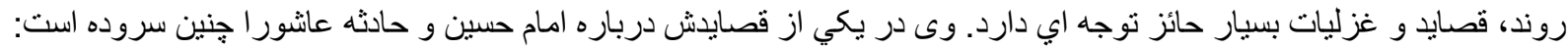

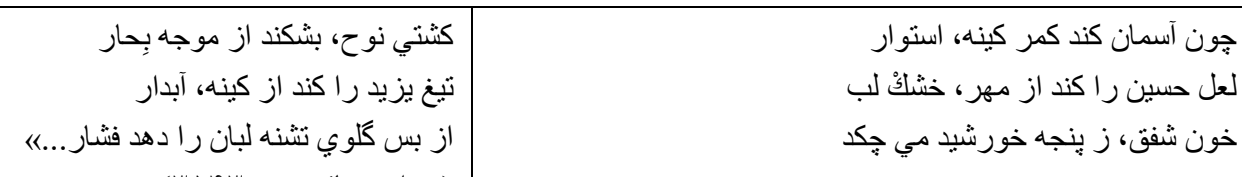

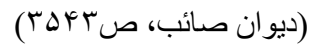

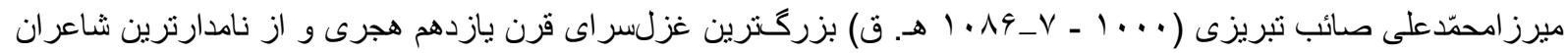
عصر صفويه است كه اشعار زيادي را در وصف و مدح شهيدان كربلا و ر رثاى امام حسين(ع) سروده است كه در اينجا به برخي از آنها اشاره مي شود:

\begin{tabular}{|c|c|}
\hline 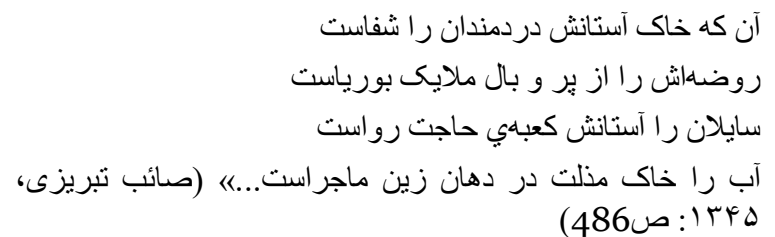 & 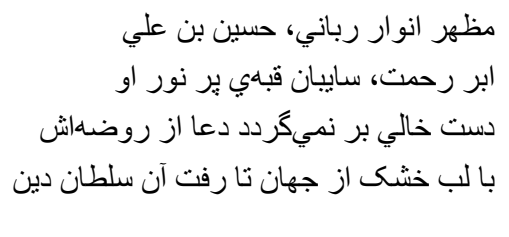 \\
\hline
\end{tabular}

صائب با بكاركيرى وجه شباهت دردهاى سينه ي خود به كربلاي دردها گفته است:

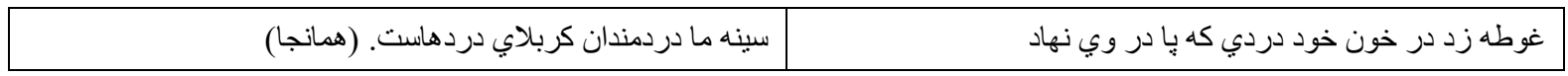

ملا محسن فيض كاشاني(1007-1007 هـ. ق) نيز بابهره كيرى از وجه عاطفى و احساسى عاثور ا با اشاره بـه كريان بودن مؤمنان در ايام محرم كفته است: ملكن فئن دكر آمد محرم تا كه ما را جسم و جان كريد..." (فيض كاشاني، ص

دكر آمد محرم تا كه جشم مؤمنان كريد

ميرزا عبدالقادر بيدل دهلوي(1054-133 هـ. ق) نيز از ديكر سخن سرايان شهير بارسى گُ در دهر عصر صفوى به شمار ميرود.

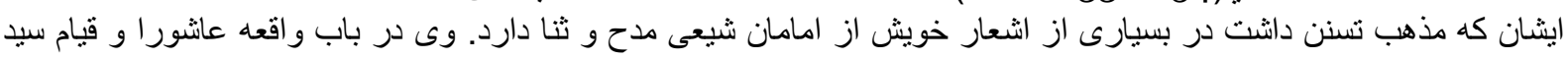

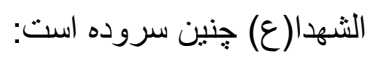

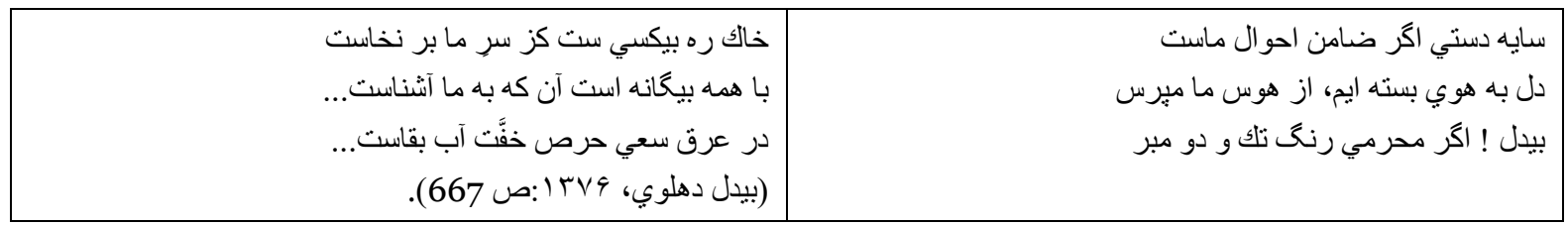

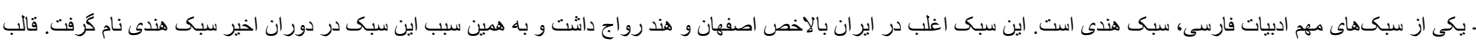

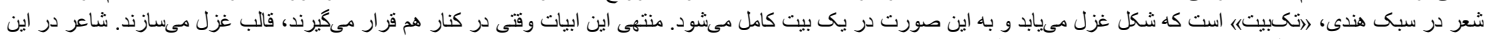

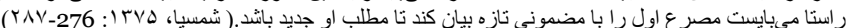


682 / RumeliDE Journal of Language and Literature Studies 2019.16 (September)

Reflection of the event of Ashura and the uprising of Imam Hossein (AS) in Persian poems from the power of Safavid until contemporary periods / A. Yeşil (p. 677-692)

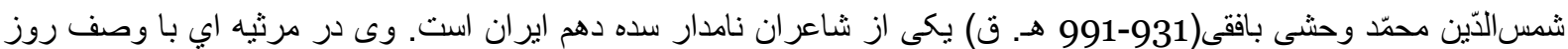

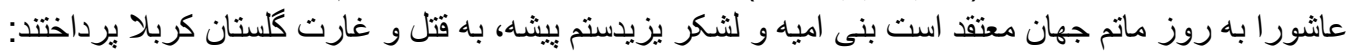

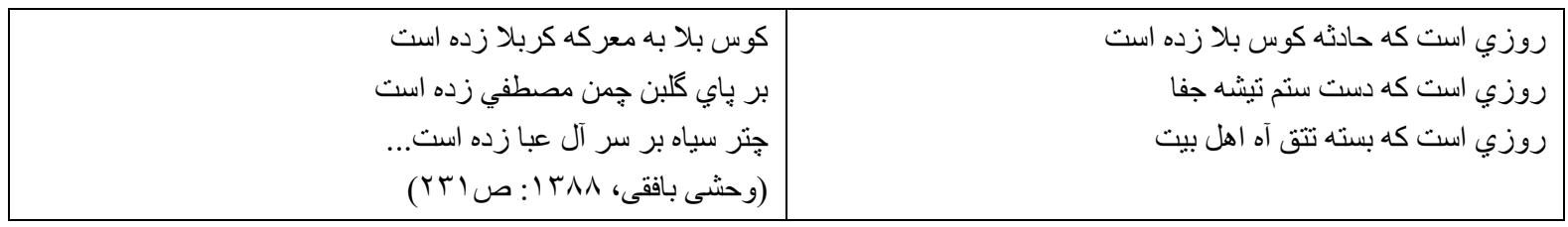

ميرز ا محسن تأثير تبريزى، متخلص به 》اتأثير ) از سخنوران شيعى اير ان كه به سال 1060 هـ. ق. متولد شده است، بابيان مصائب و ستم هايى كه بر عانثور ائيان رفت جنين سروده است:

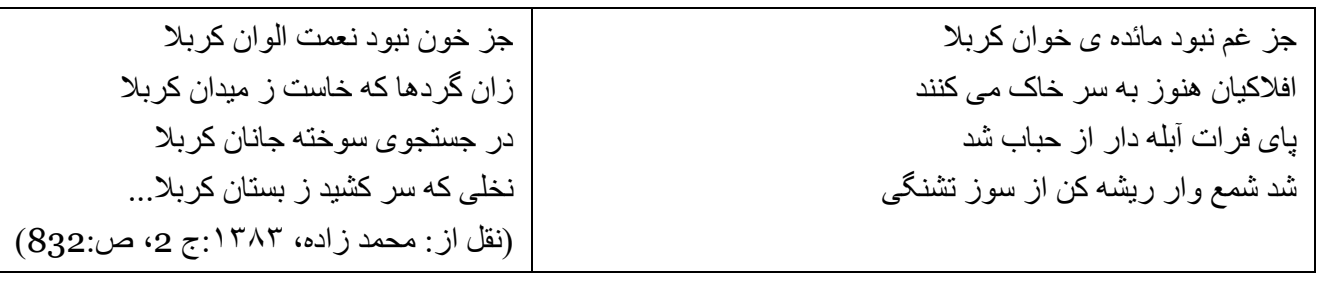

محمدعلى بن ابىطالب زاهدى كيلانى(منولد ب ـ ـ 11 هـ. ق) اديب، عالم و سخن سراى شيعى اير انى كه به حزين لاهيجى شهرت دارد، در باب قيام عاثور او والثاثثه كربلا مى سرايد:

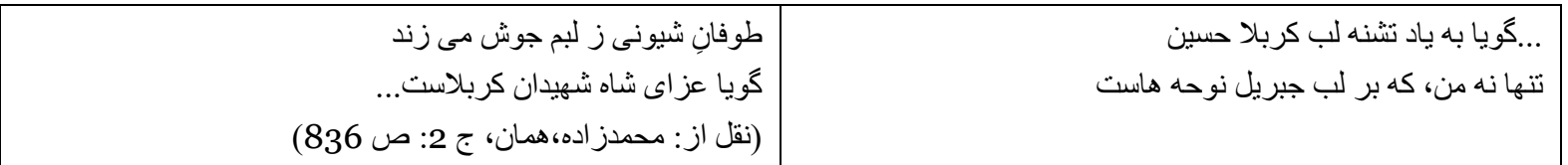

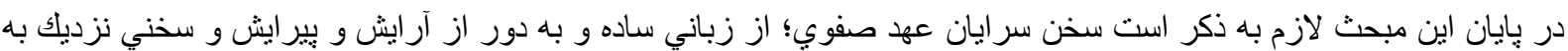

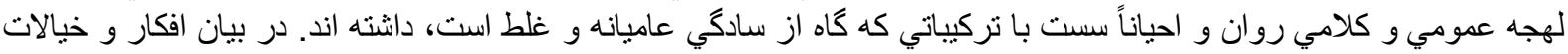

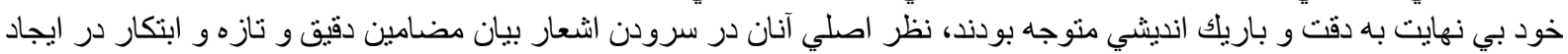

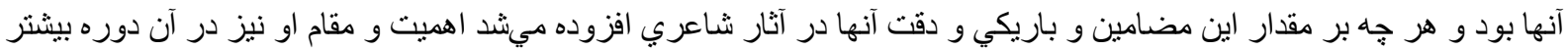

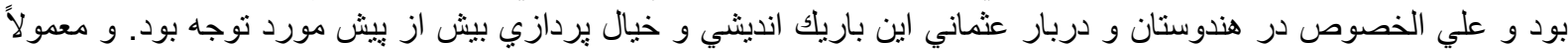

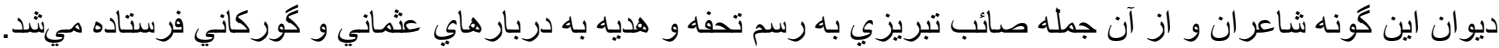

\section{دوره افثشاريه تا بايان بـهلوى}

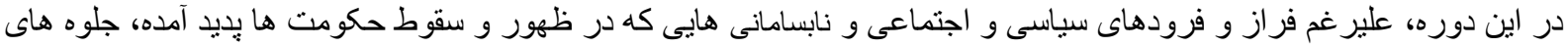

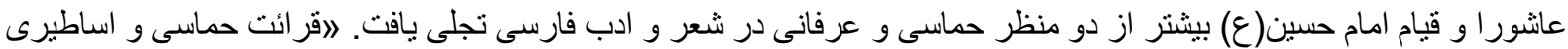

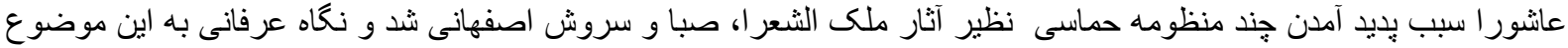

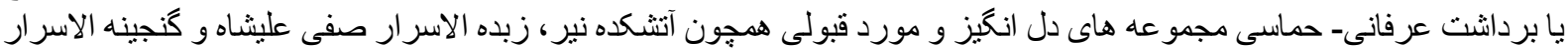

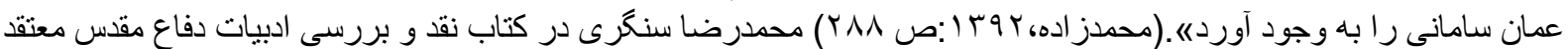

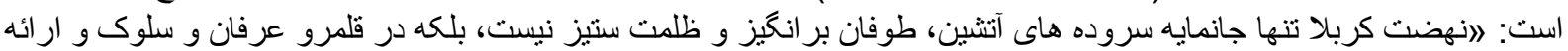

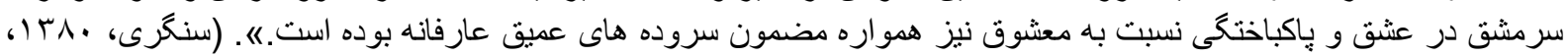

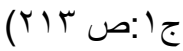

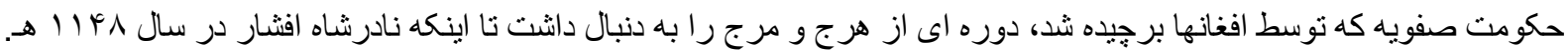

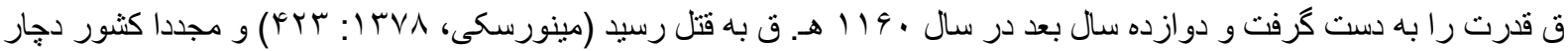

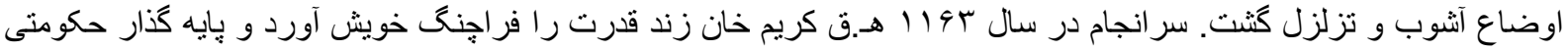




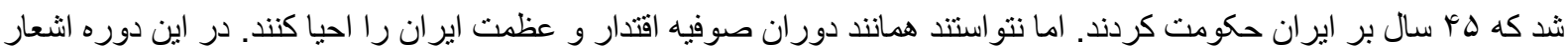

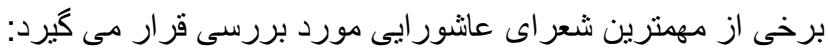

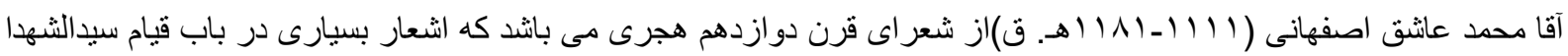

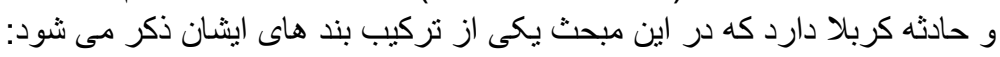

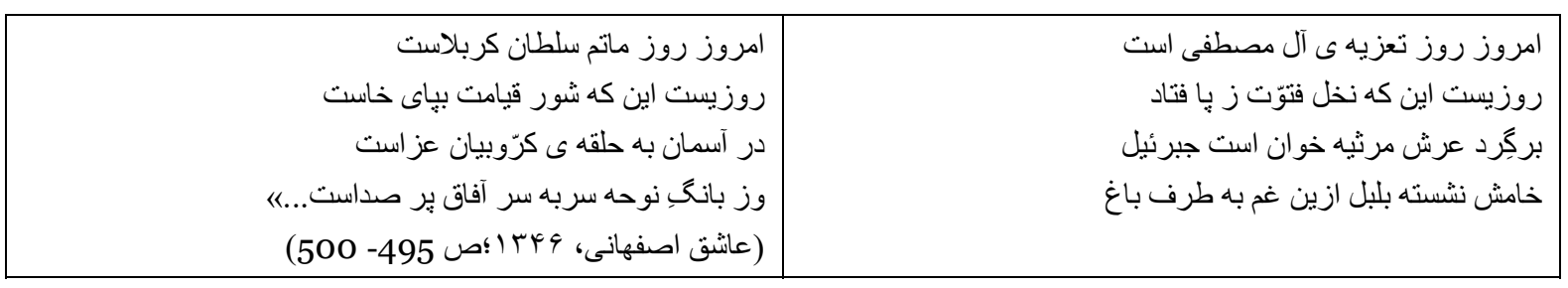

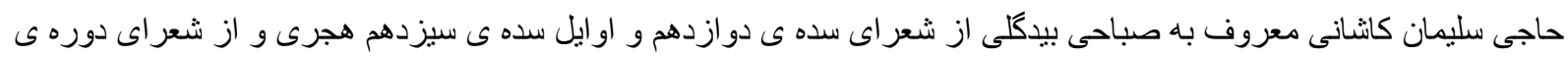

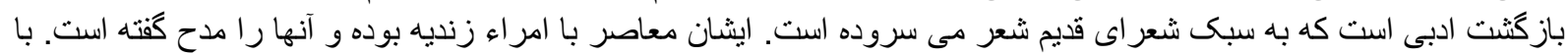

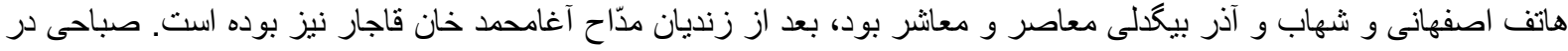

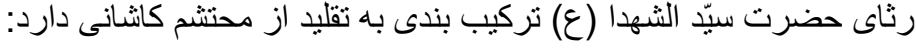

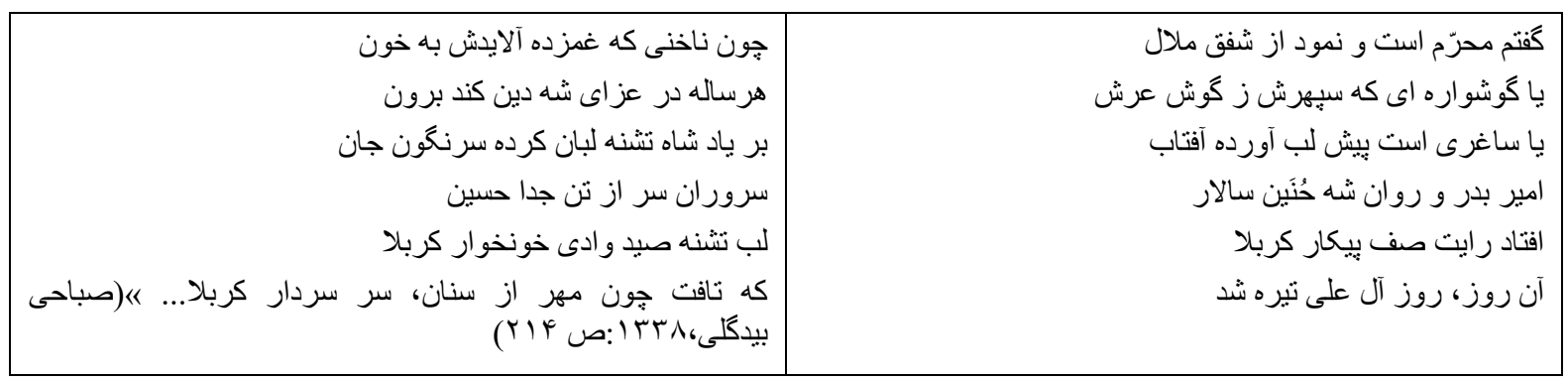

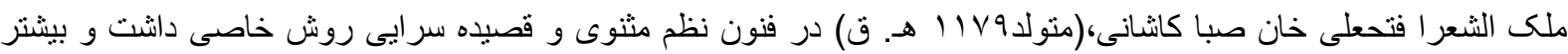

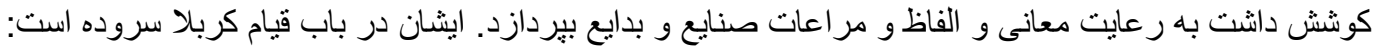

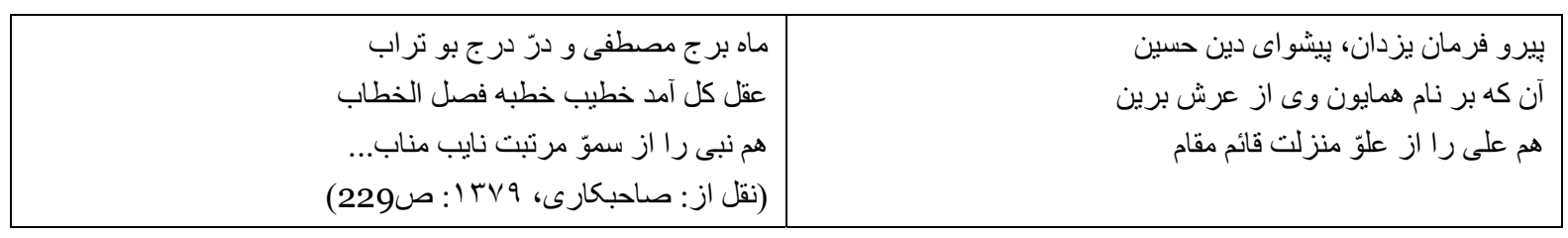

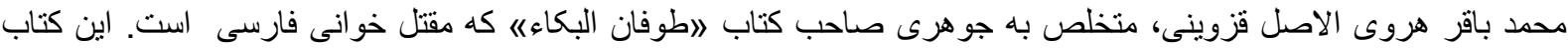

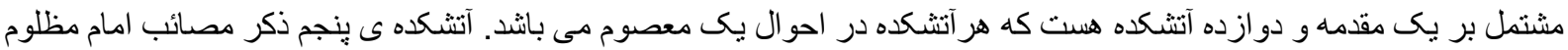

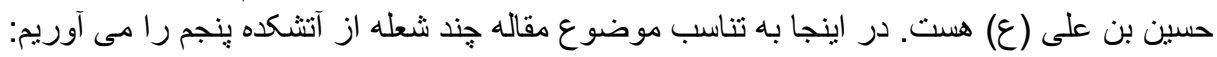

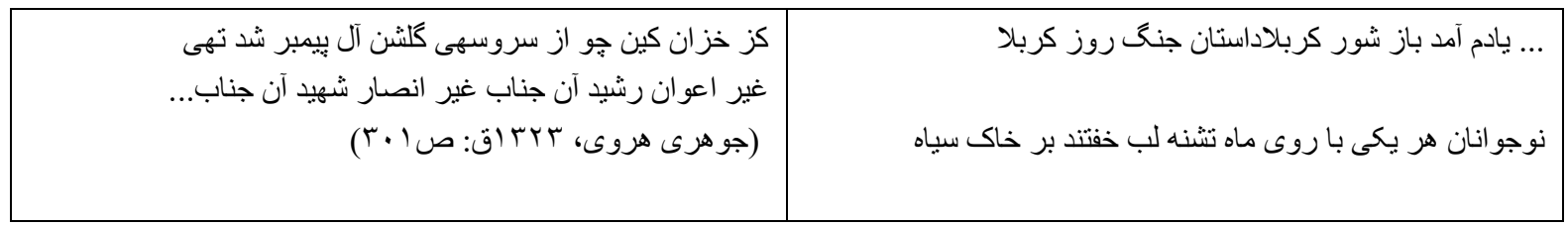


684 / RumeliDE Journal of Language and Literature Studies 2019.16 (September)

Reflection of the event of Ashura and the uprising of Imam Hossein (AS) in Persian poems from the power of Safavid until contemporary periods / A. Yeşil (p. 677-692)

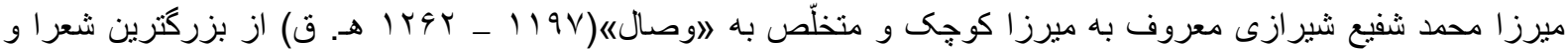
غزلسر ايان مشهور اوايل دورهى قاجاريه است. همه به مكر و دَغَل جفت و از مرّوت، طاق... (شيرازى، بى تا: ص

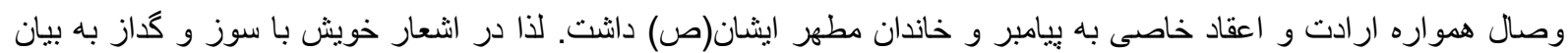

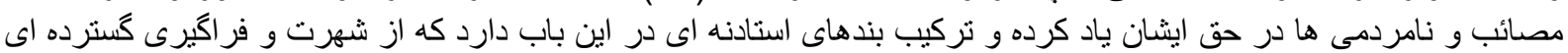

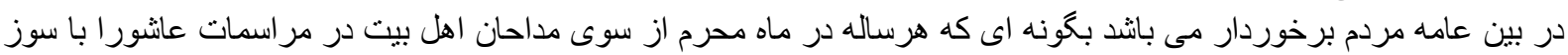

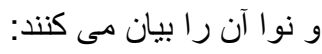

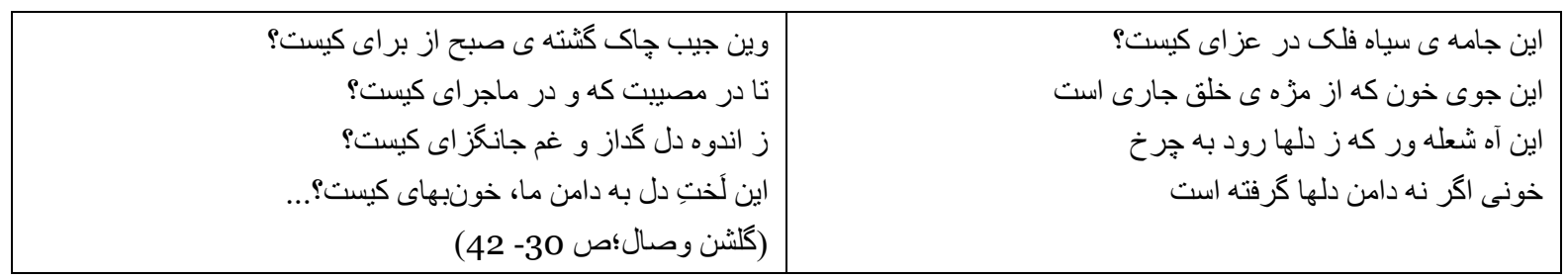

وصال شير ازى در برخى از اشعار خويش با حمله به قدرنشناسى كوفيان در يارى رسانى به امام حسين، آنان را مورد عتاب قرار مى دهد و در شعرى جنين سرود است:

$$
\begin{aligned}
& \text { زَ امّت كِى بوَد فرزند كُشتنَ، مزد بِيغامش؟؟... }
\end{aligned}
$$

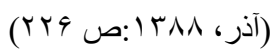

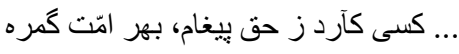

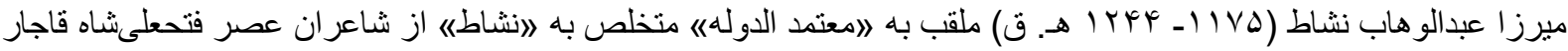
مسى باشد. مير

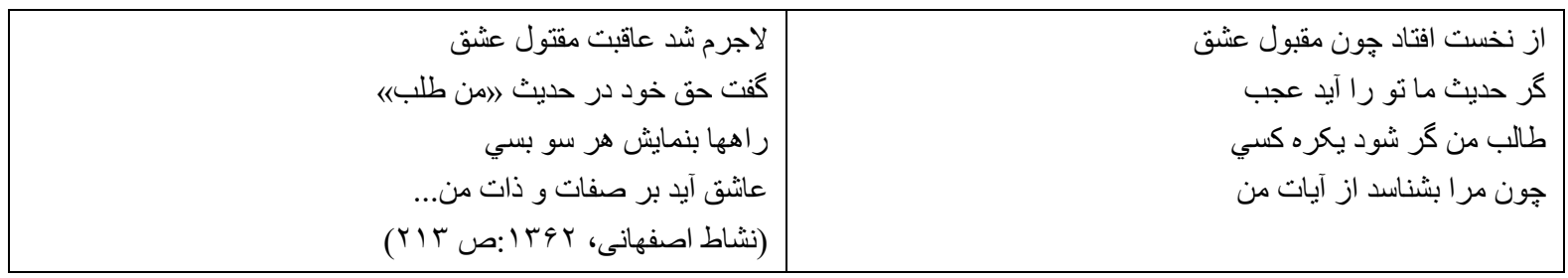

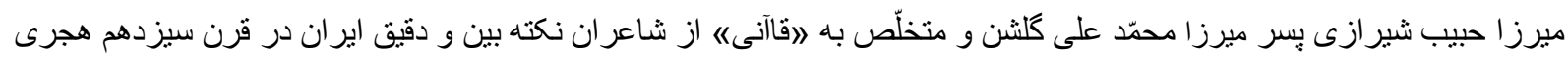

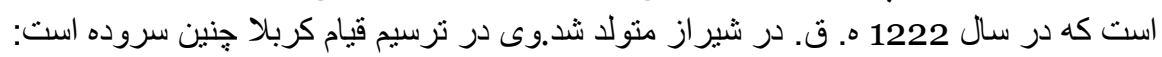

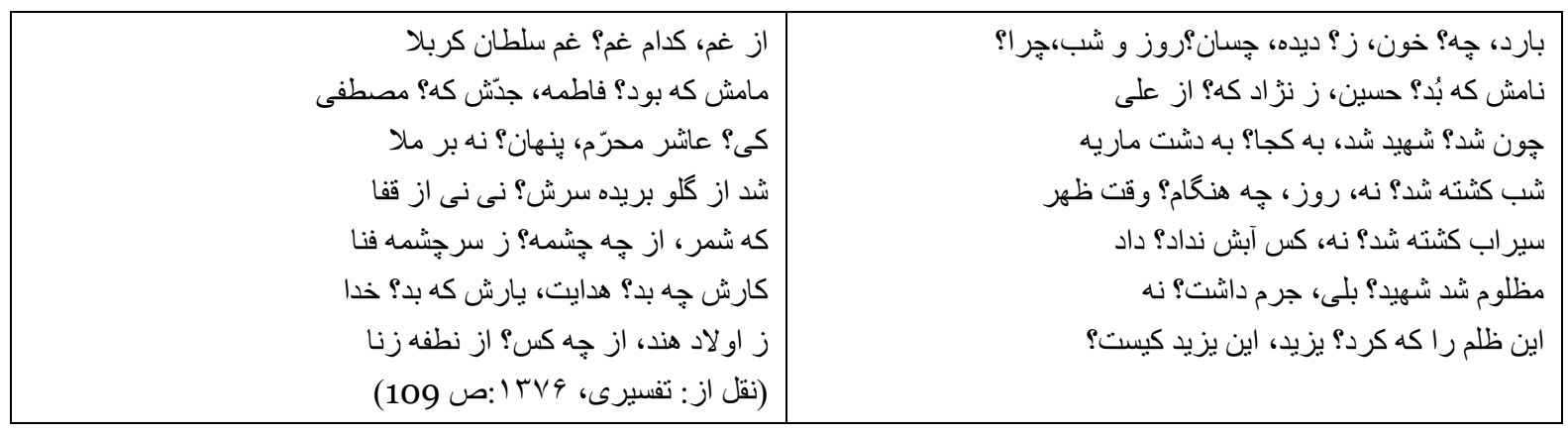


ابو الحسن بن ابر اهيم قلى يغماى جندقى، از شاعر ان معروف قرن سيزدهم غزلسر ایى دوره ى قاجارى است. وى در يكى از اشعار

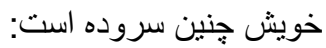

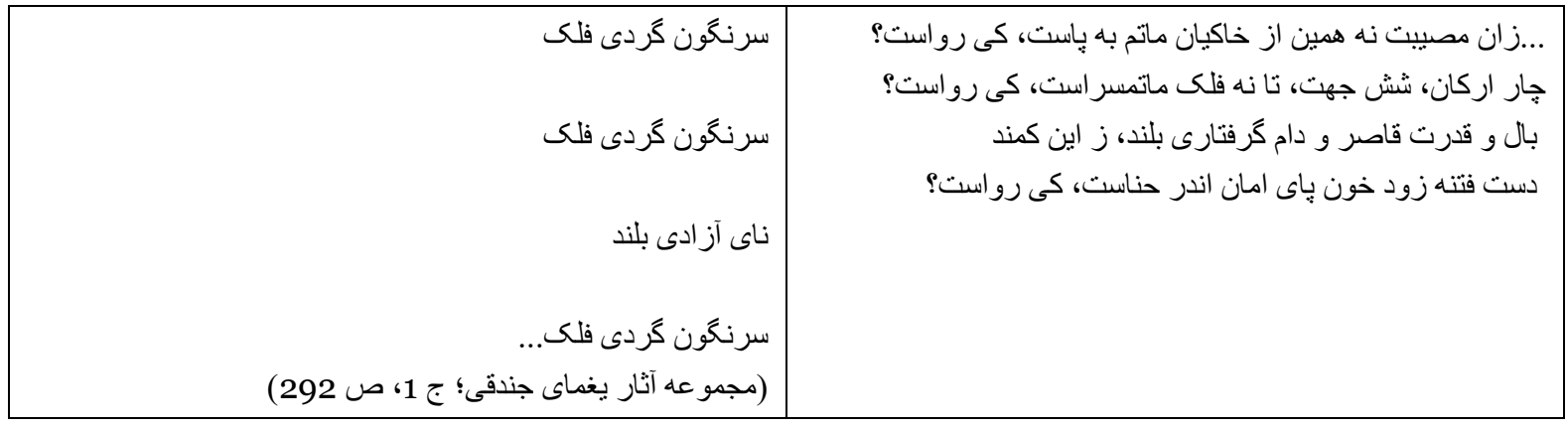

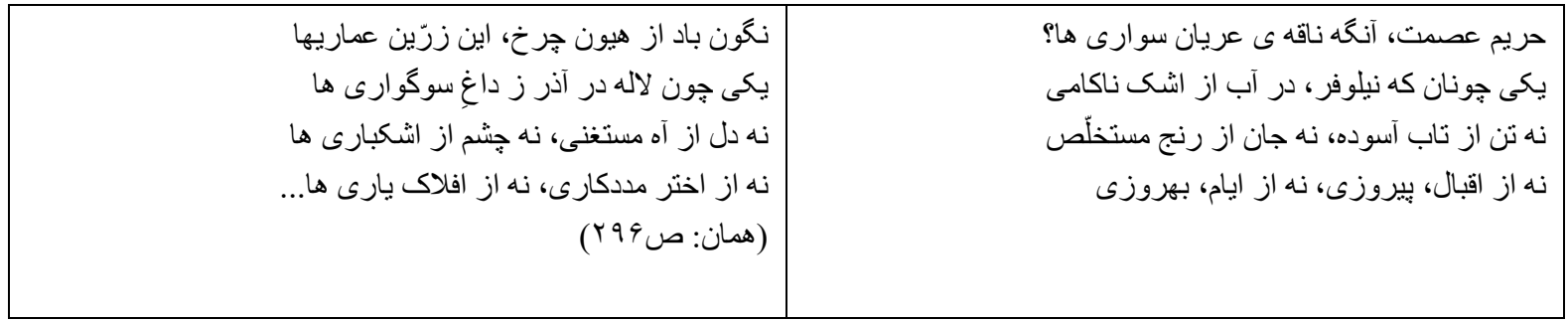

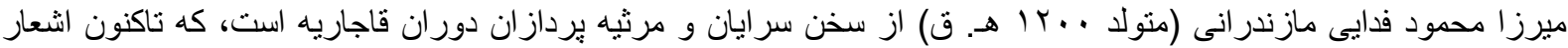

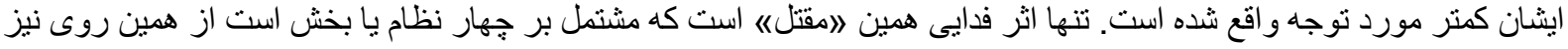

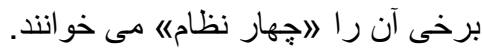

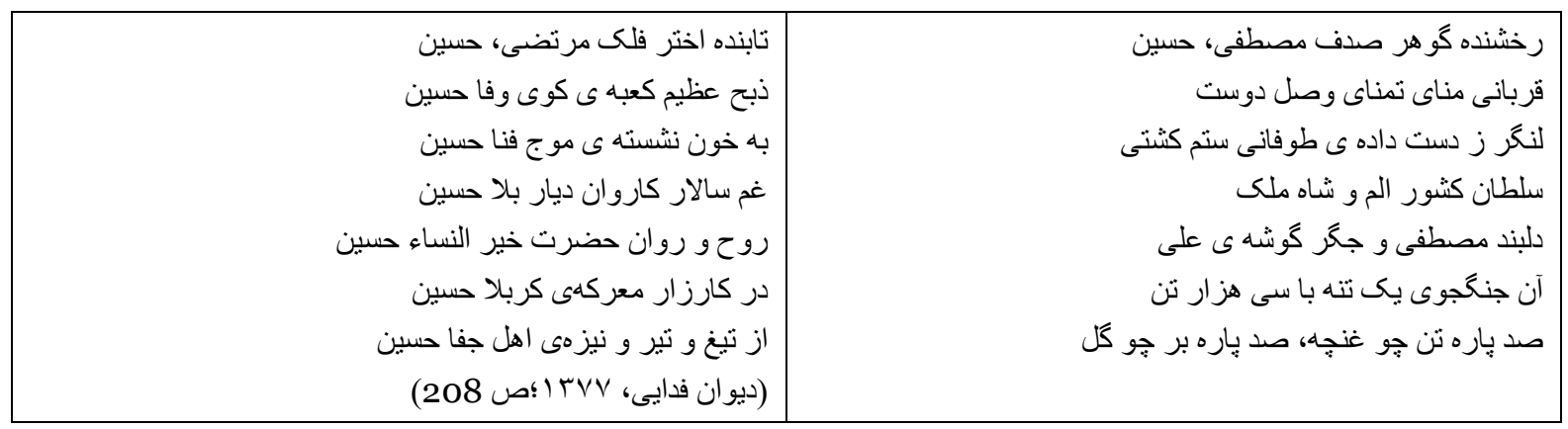

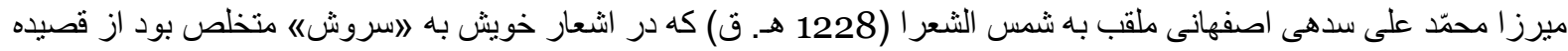

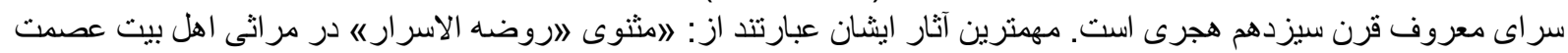

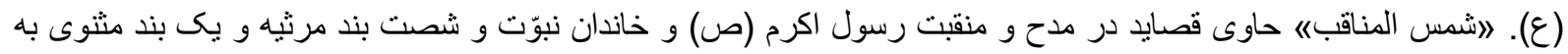

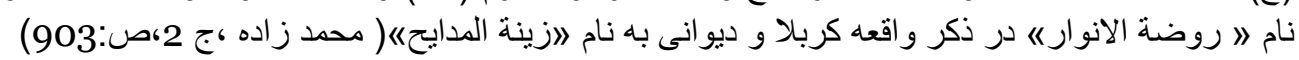

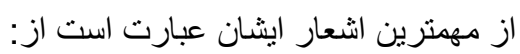

\begin{tabular}{|c|c|}
\hline 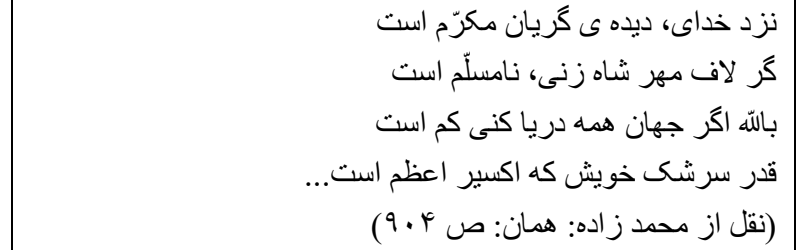 & 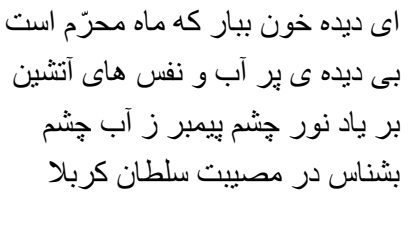 \\
\hline
\end{tabular}


686 / RumeliDE Journal of Language and Literature Studies 2019.16 (September)

Reflection of the event of Ashura and the uprising of Imam Hossein (AS) in Persian poems from the power of Safavid until contemporary periods / A. Yeşil (p. 677-692)

ميرزا محمّد على شيرازى مشهور به رضاقلى خان كه در اشعار به لهماى شيرازىه متخلص بود، از شاعران بر نوان قرن سيزدهم هجرى است.در يك تركيب بند جنين سروده است:

$$
\begin{aligned}
& \text { از زير فرش تازبر عرش كردكار }
\end{aligned}
$$

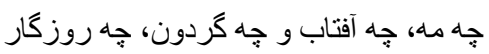

$$
\begin{aligned}
& \text { بر هر جه بكذرى به مصيبيت نثسته زئه زار }
\end{aligned}
$$

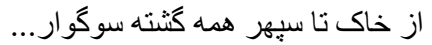

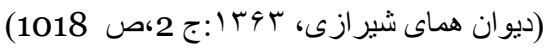

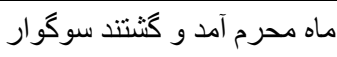

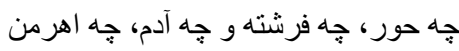

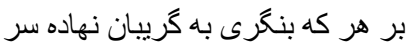

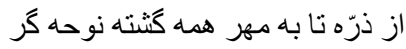

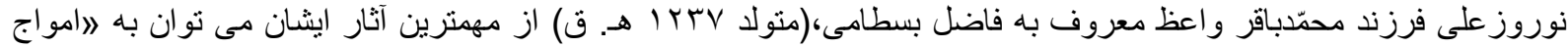

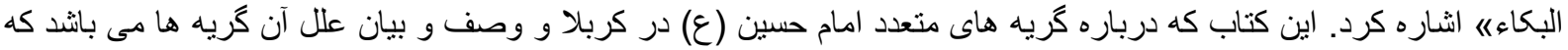

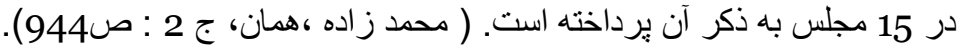

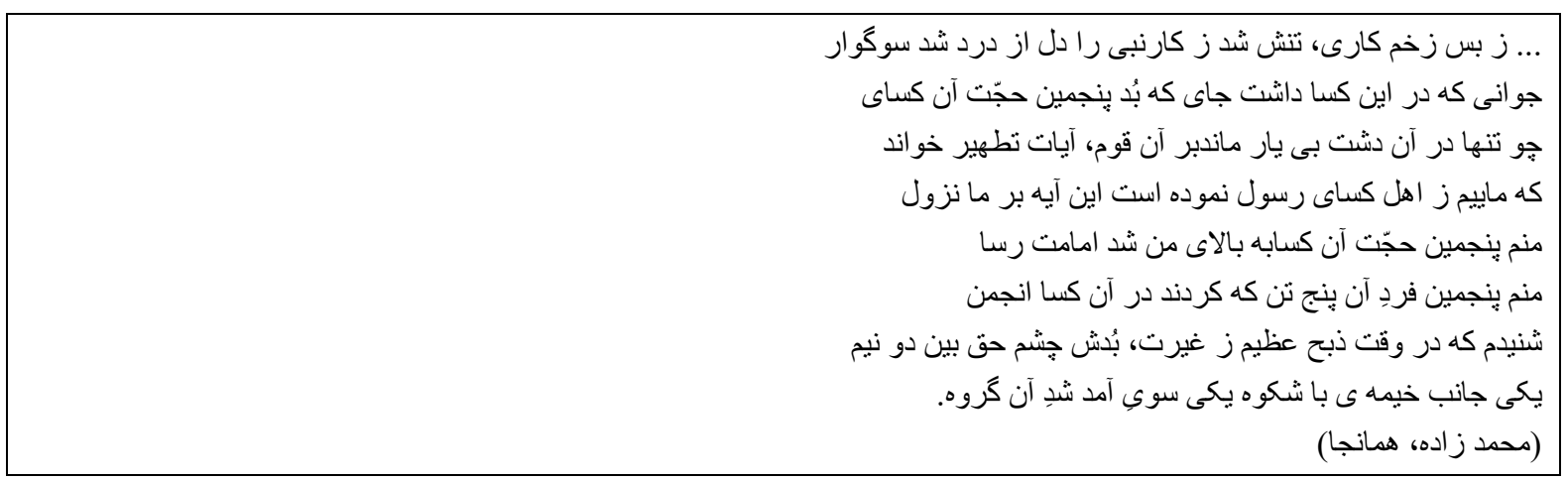

محمود خان ملى الثعر اء صبا(متولد Ir I ا هـ. ق)در تركيب بندى جنين سروده است:

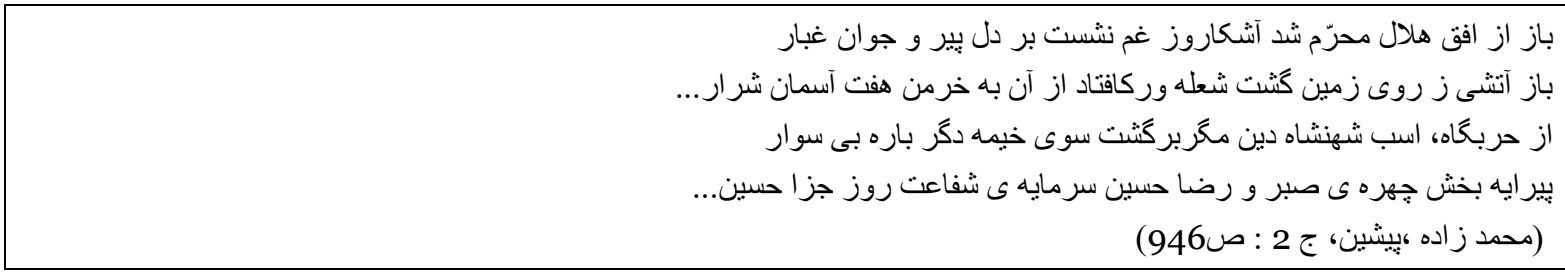

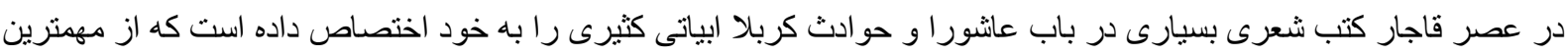

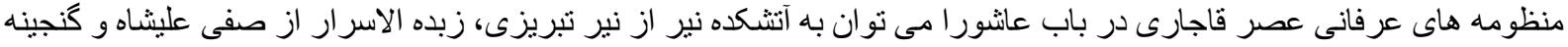

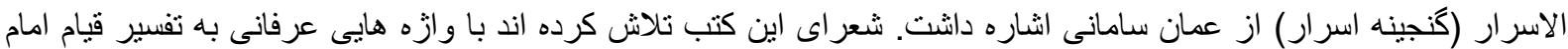
حسين(ع) بيردازند.

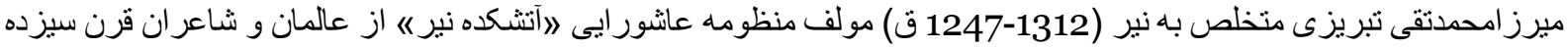

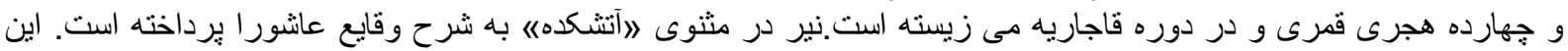

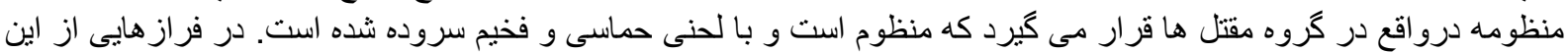

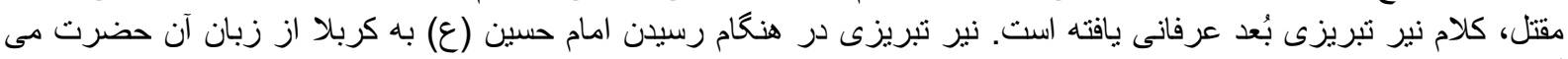

\begin{tabular}{|c|c|}
\hline 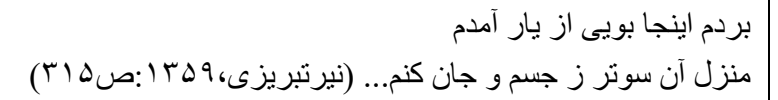 & 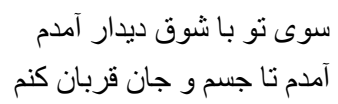 \\
\hline
\end{tabular}


ايثان علاوه بر مثنوى ذكر شده، تركيب بندى بيست و هشت بندى به همر اه جند غزل، رباعى و دوبيتى ديكرى كه نير دربارهى وقايع روز عاثشور اسروده است:

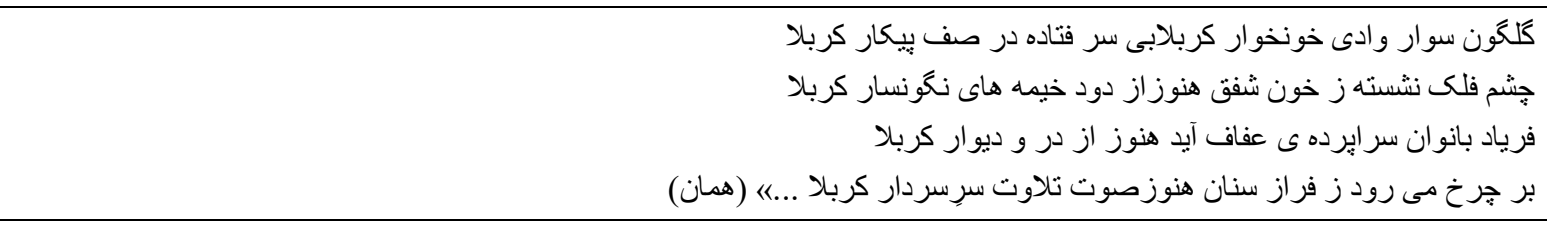

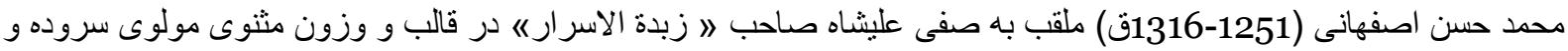

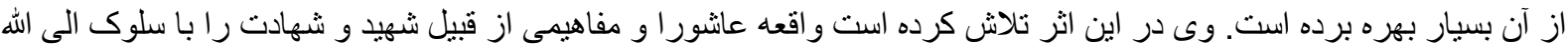

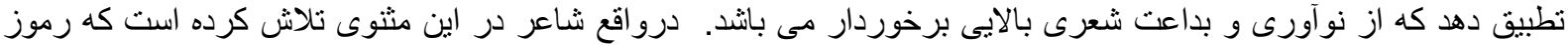

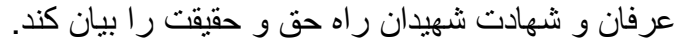

\begin{tabular}{|c|c|}
\hline 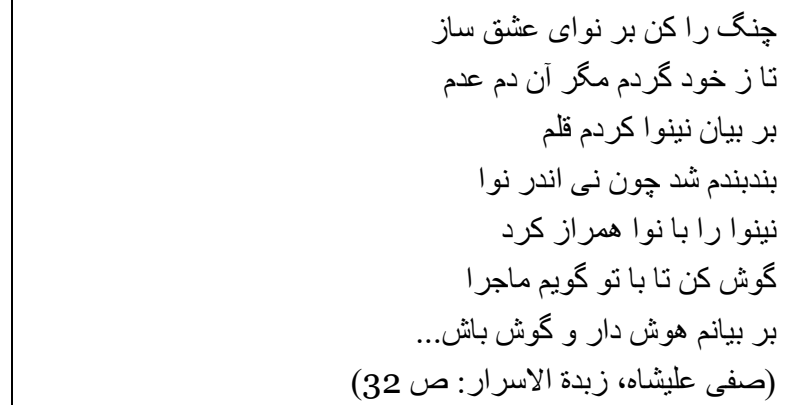 & 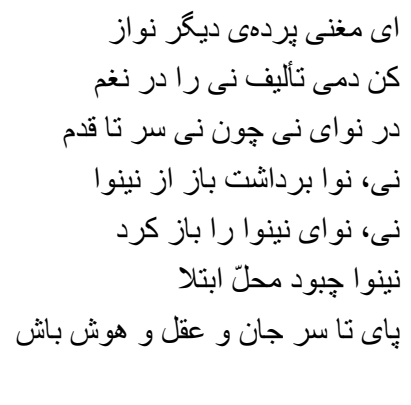 \\
\hline
\end{tabular}

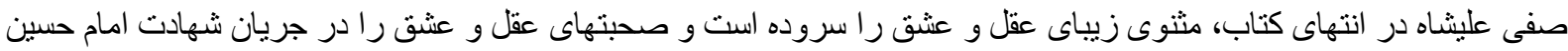

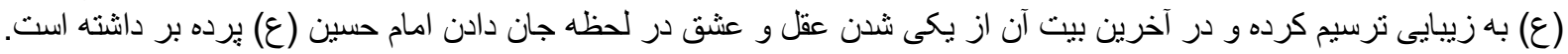

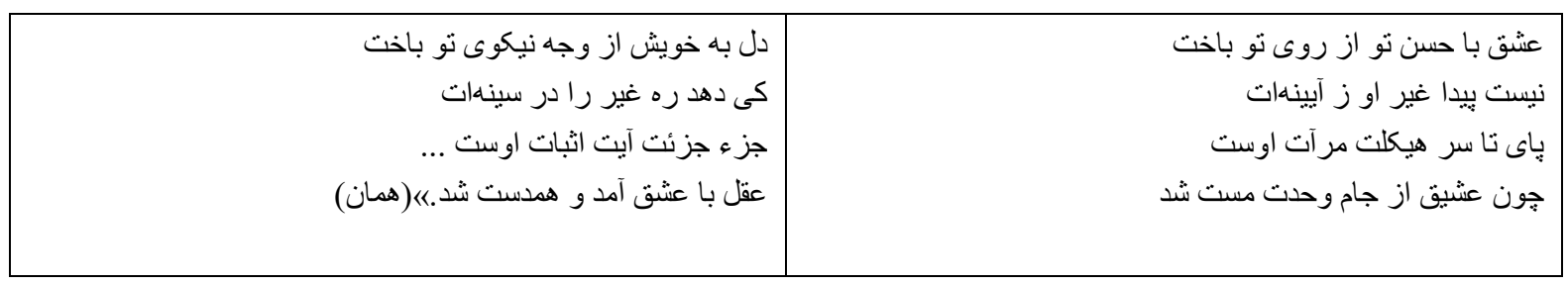

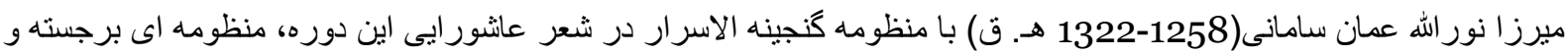

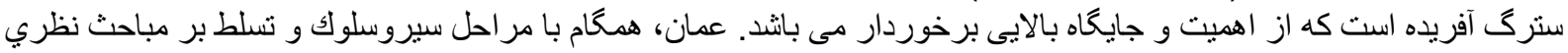

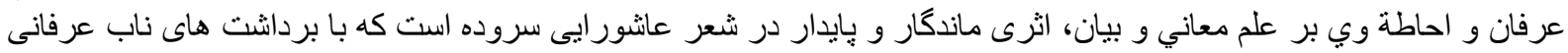

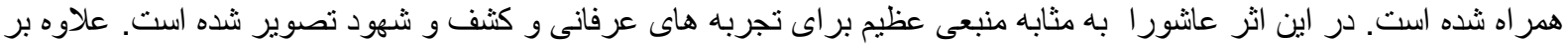

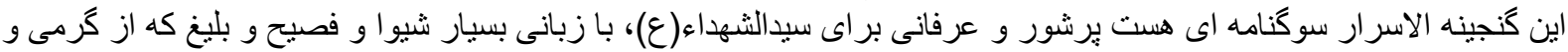

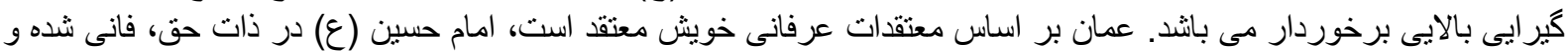
حق در ايثان تجلى كرده است.

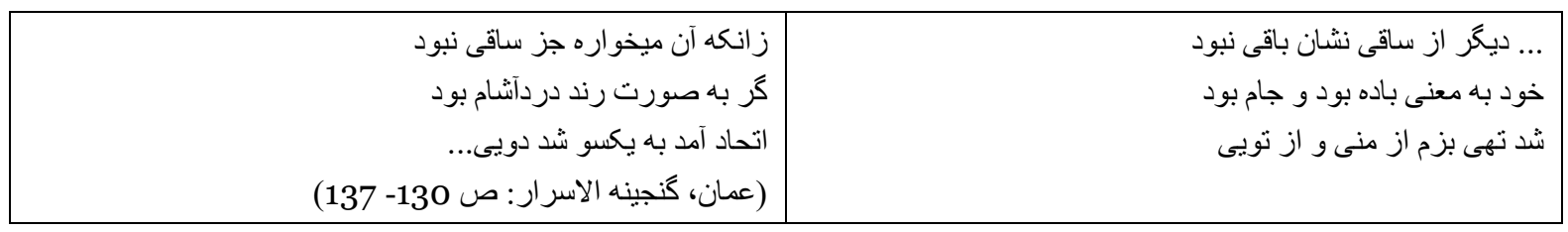


688 / RumeliDE Journal of Language and Literature Studies 2019.16 (September)

Reflection of the event of Ashura and the uprising of Imam Hossein (AS) in Persian poems from the power of Safavid until contemporary periods / A. Yeşil (p. 677-692)

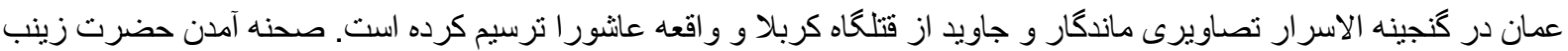

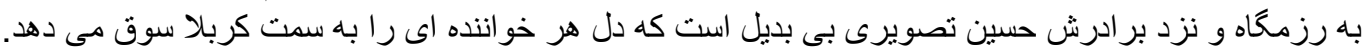

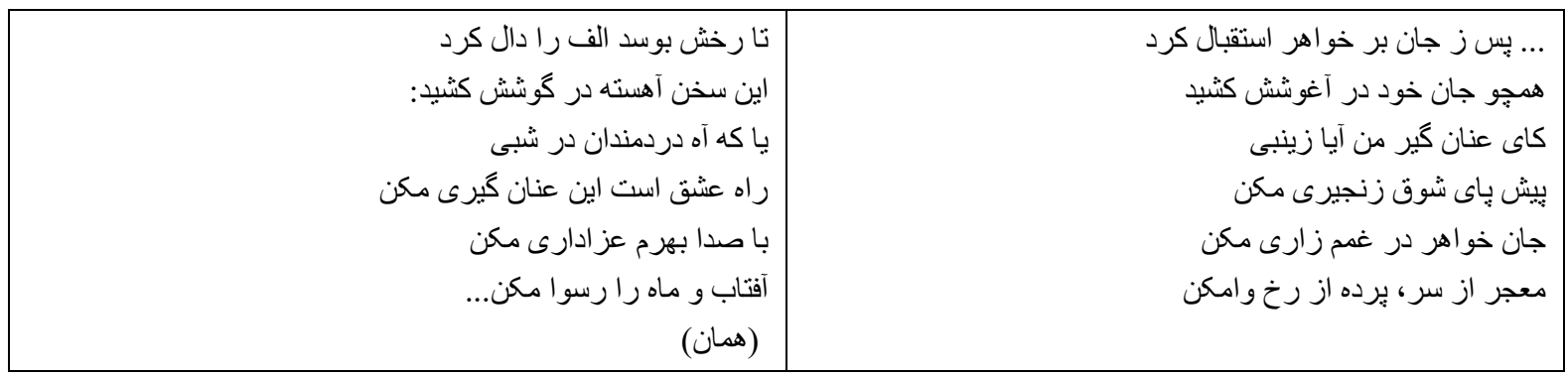

اديب الممالك فراهانى(متولد I IVV هـ. ق)وى از شاعر ان عصر مشروطه به شمار مى رود:

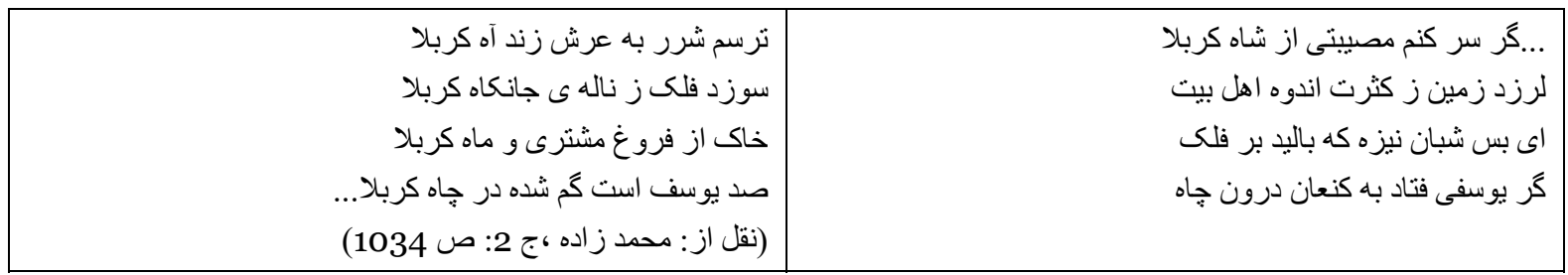

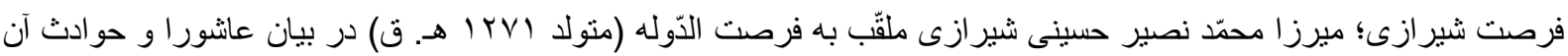

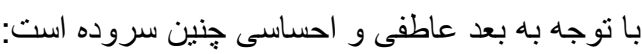

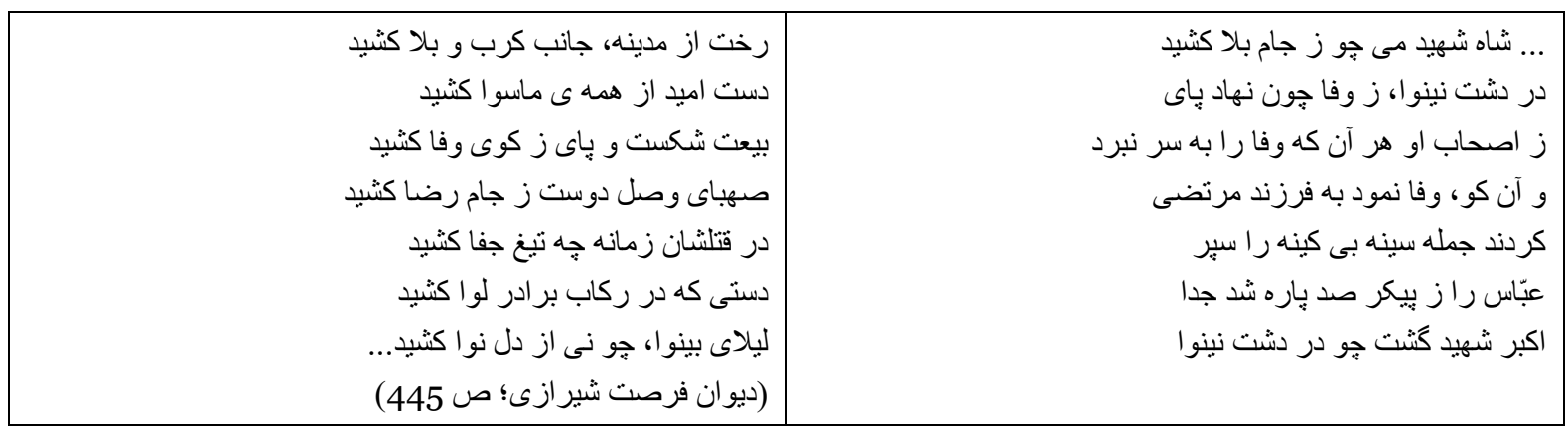

محمد صادق سمنانى متخلّص به لارفعته، از شاعران دوران مشروطيّت. ابياتى از قصيده ايشان بيان مى شود:

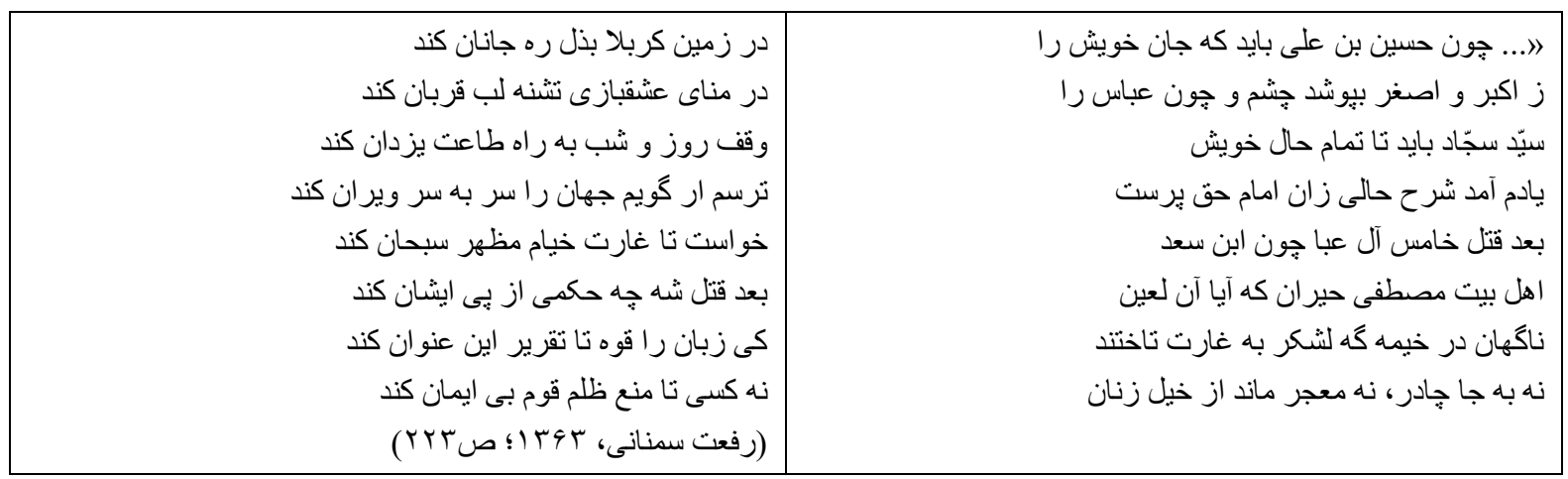




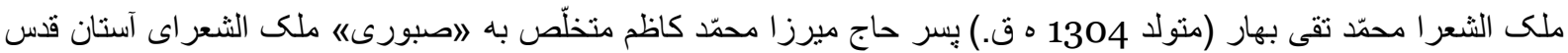

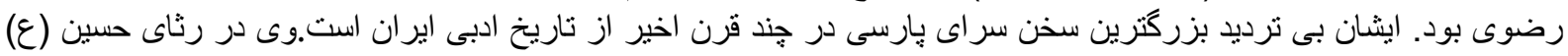
جنين سروده است:

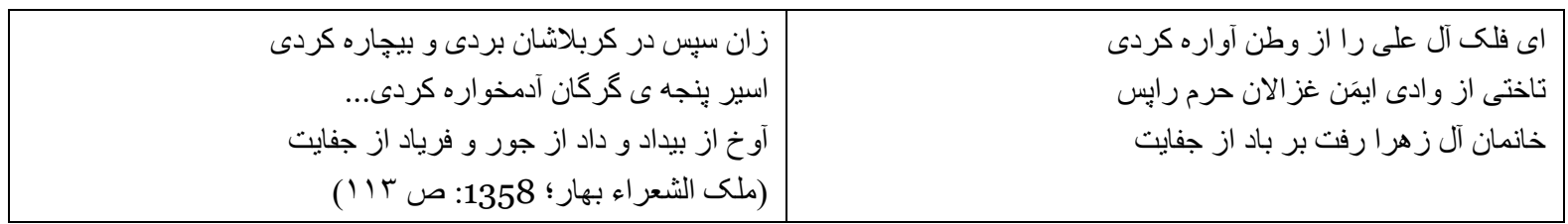

ابو القاسم الهامى (لاهوتى) منولد هـ ـ آ هـ. ق ، شاعر عصر مشروطه و يهلوى تلاش كرده است تصاويرى واضح از عاشورا و وقايع بيش آمده ار ائه كند:

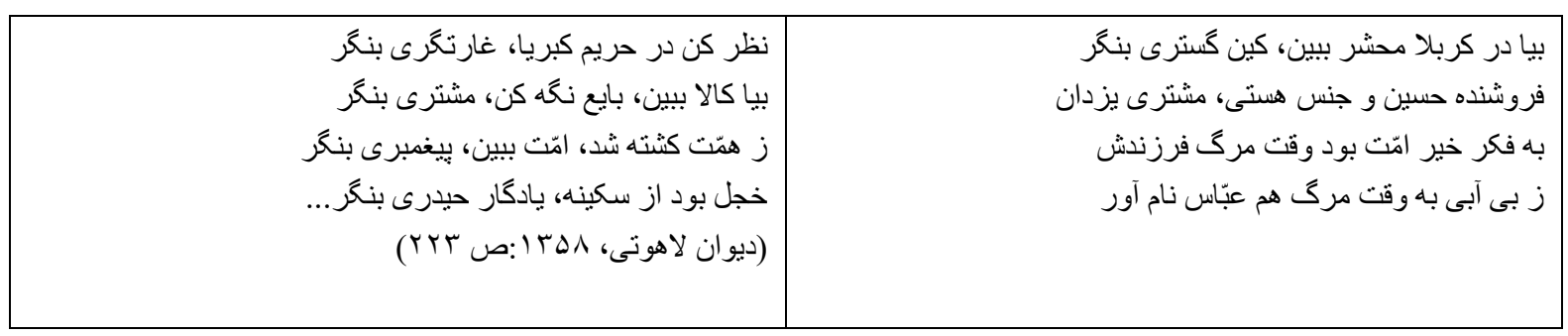

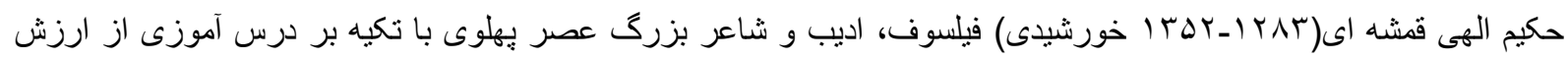

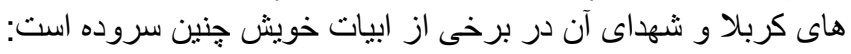

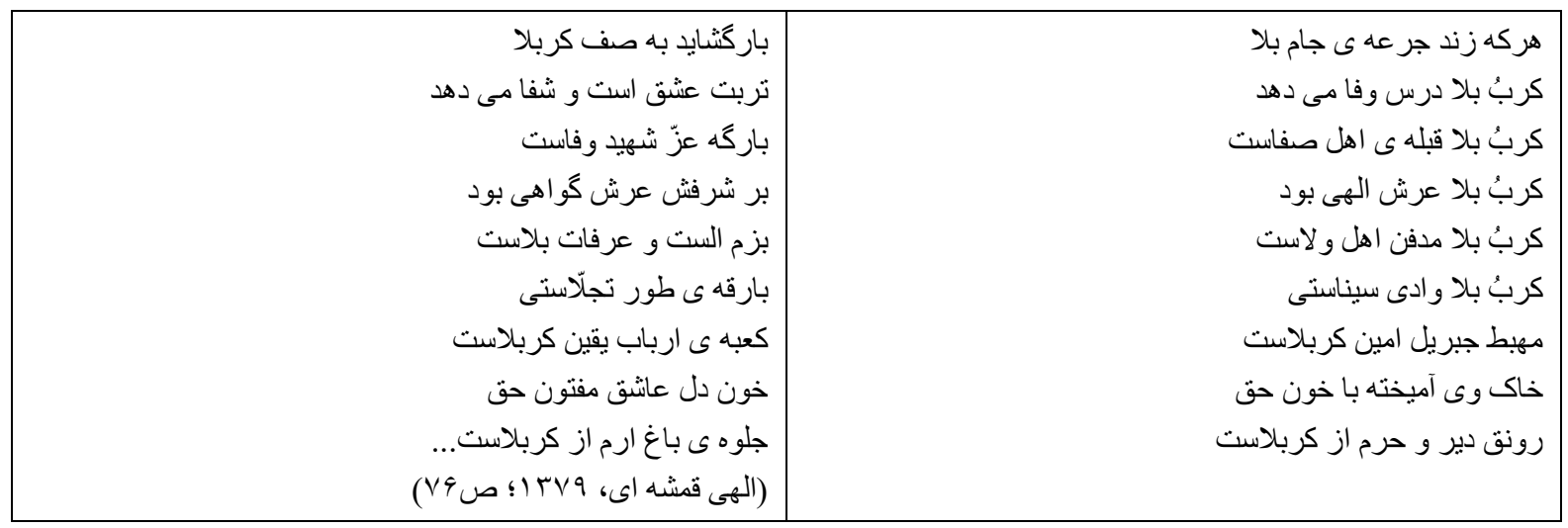

محمّد كاظم طوسى(متوفى VT ا خورشيدى) سخن سراى عصر يُهلوى در باب كربلا و قيام سيد الثهدا جنين سروده است:

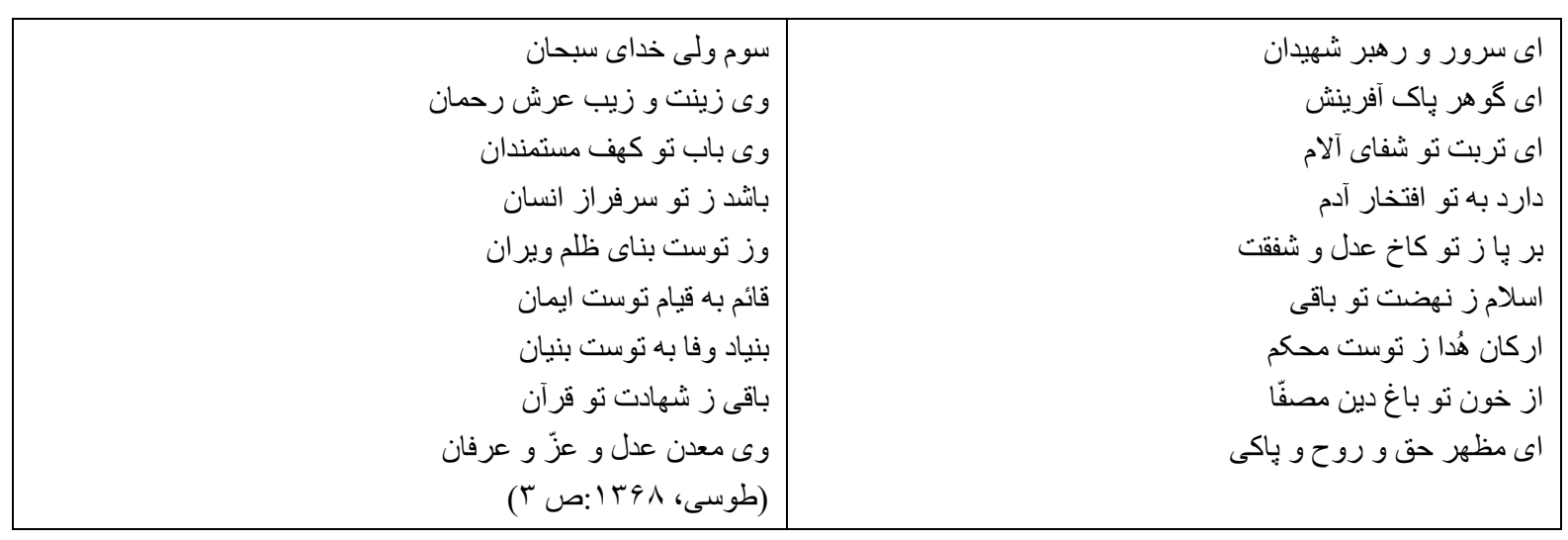


690 / RumeliDE Journal of Language and Literature Studies 2019.16 (September)

Reflection of the event of Ashura and the uprising of Imam Hossein (AS) in Persian poems from the power of Safavid until contemporary periods / A. Yeşil (p. 677-692)

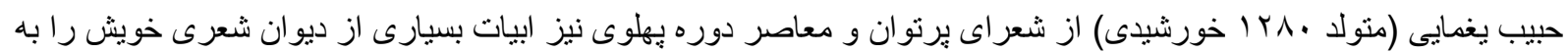

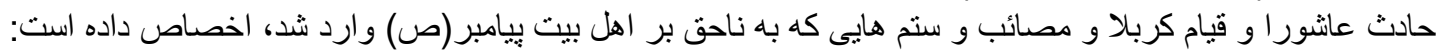

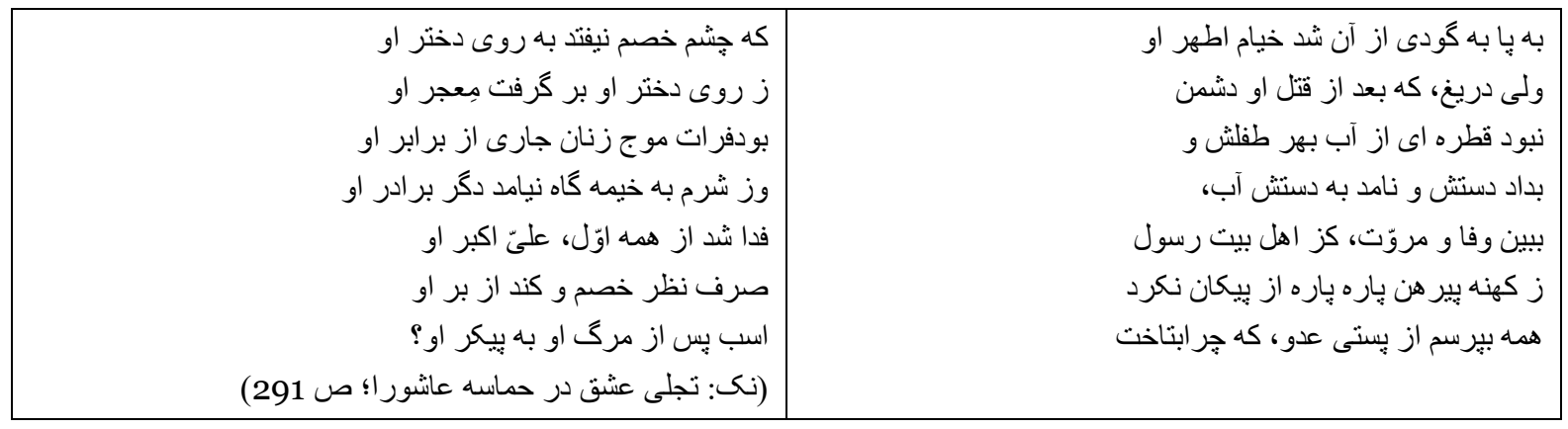

حسين مسرور (متولا 1 • rا هـ. ق)سخن سراى عصر بهلوى:

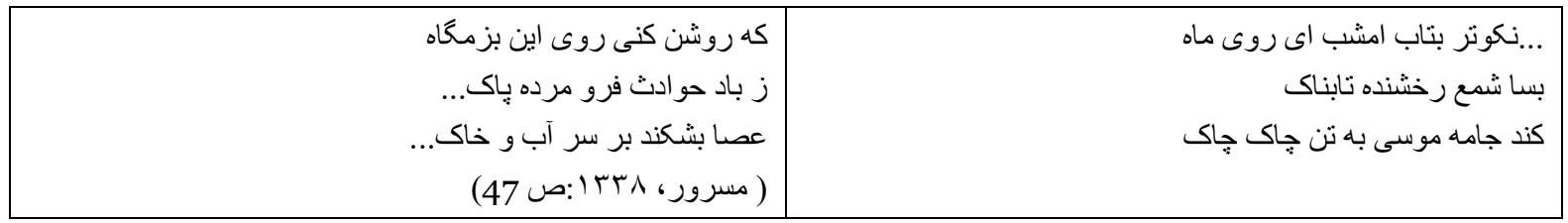

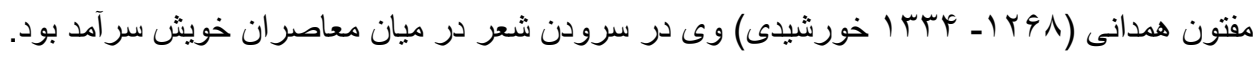

\begin{tabular}{|c|c|}
\hline 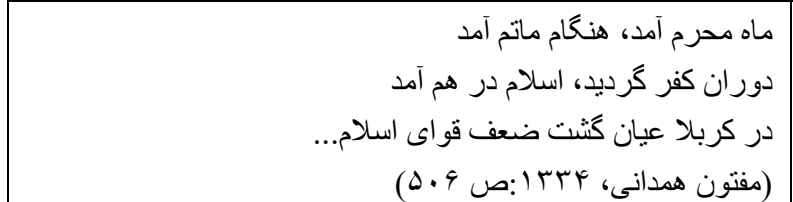 & 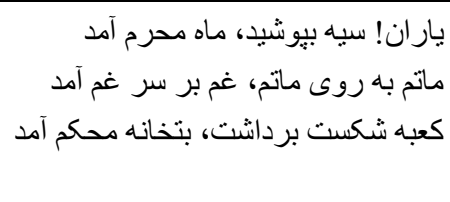 \\
\hline
\end{tabular}

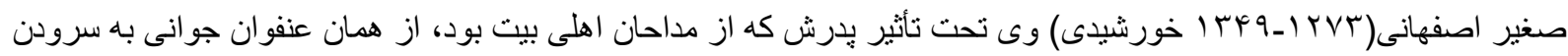
شعر در مدح و منقبت اهلى بيت(ع) برانيرداخت:

\begin{tabular}{|c|c|}
\hline 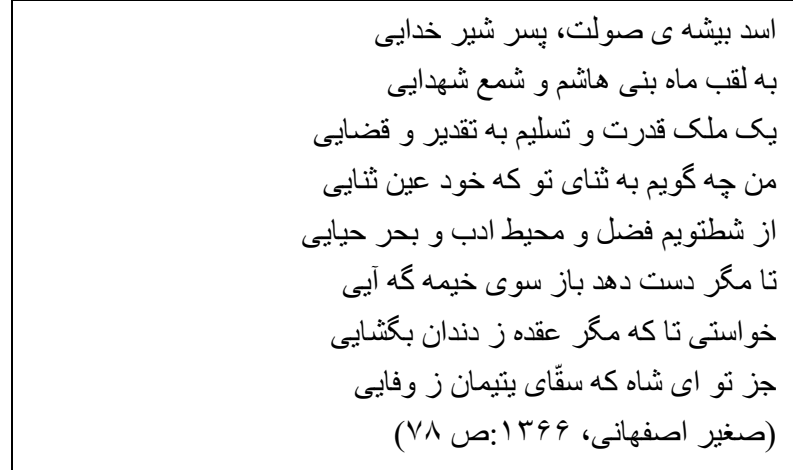 & 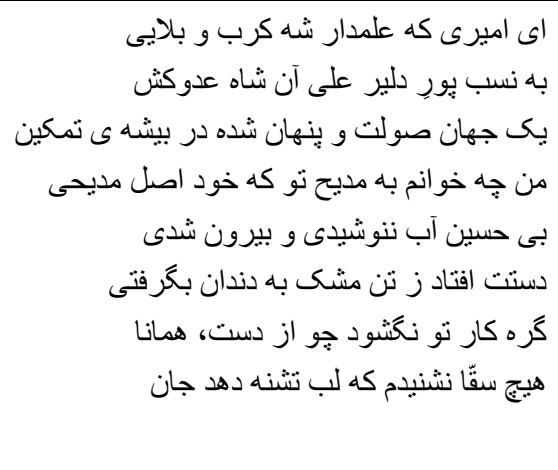 \\
\hline
\end{tabular}

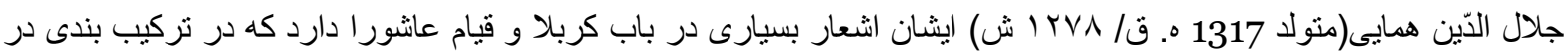
مرثيه ى عانشور إجنين سروده است:

$$
\begin{aligned}
& \text { آهنگ ساز كرده به شور و نواى عشق } \\
& \text { افكنذه است غُلُْلهُ در نينواى عشق ونق }
\end{aligned}
$$

باز اين جه نغمه است كه دستان سراى عشق ارئ

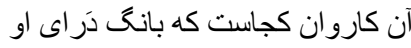




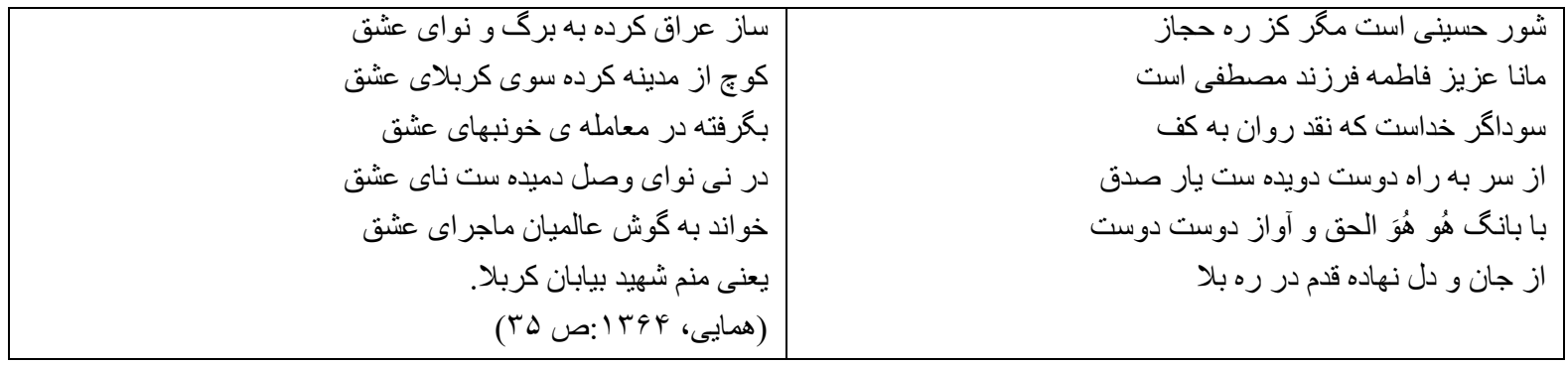

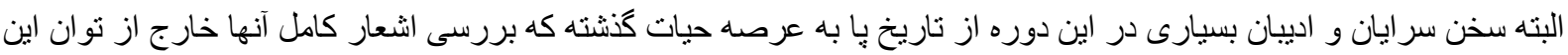

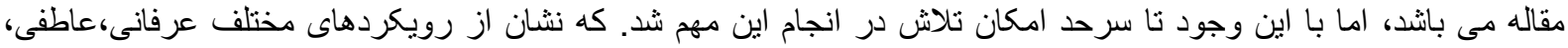

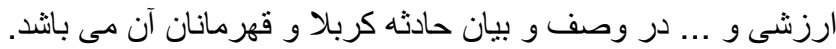

\section{نتيجه كيرى}

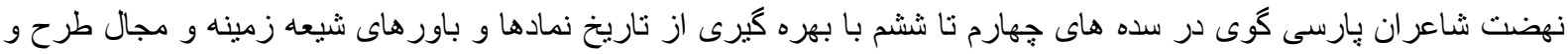

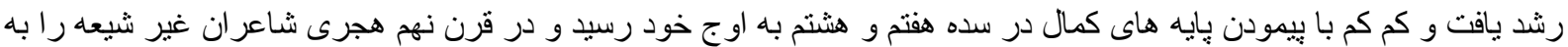

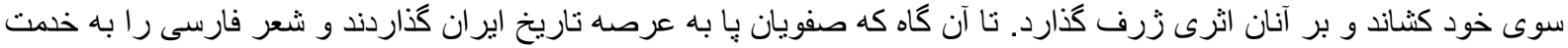
مذهب و آموزه هاى بلند آن درآوردند.

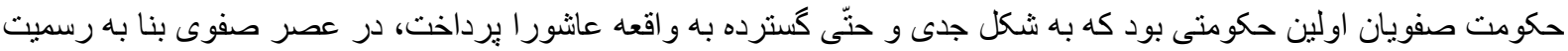

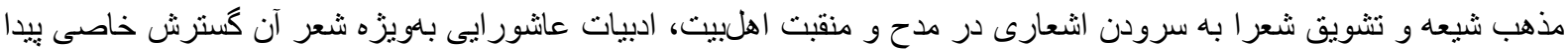

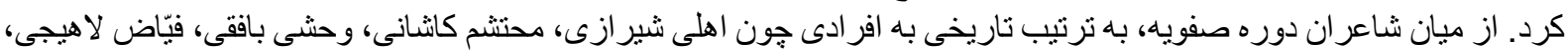

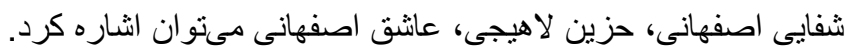

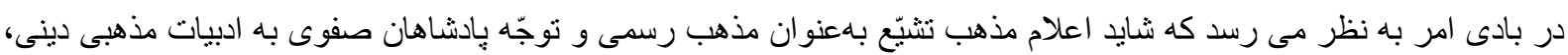

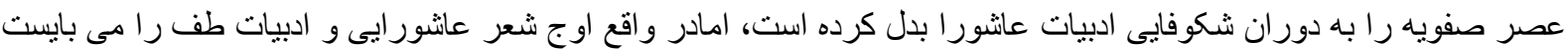

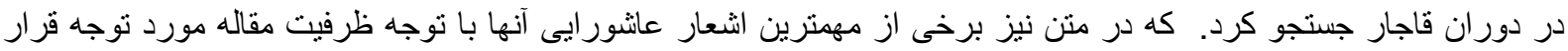

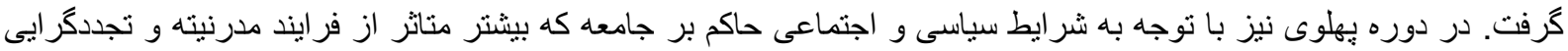

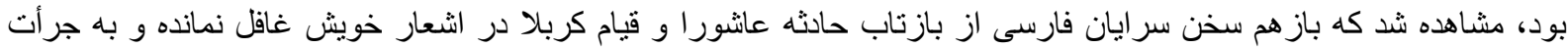

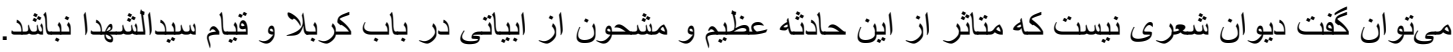

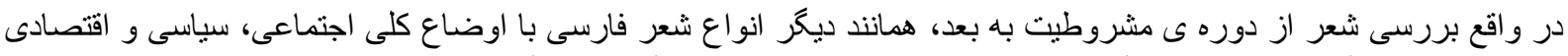

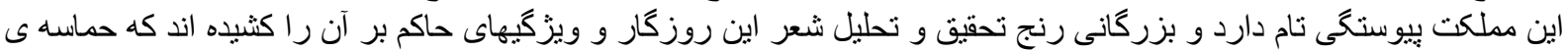

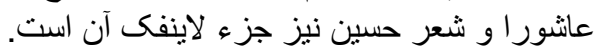

\section{Kaynakça}

Ahli Şirazi, Muhammed (1344). Kulliyat-ı eşar. Haz. Hami-i Rabbani. Tahran.

Ali-Davudi, Seyydi Ali (1357). Mecmua-i Asar-ı Yaghma-ye Jandaqi. Tahran: İntişarat-ı Tus.

Aşık-ı İsfahani (1346). Divan. Haz: Hüseyin Mekki. Tahran: İntişarat-ı Kutub-i İran.

Bîdil-i Dehlevî, Mîrzâ Abdülkādir (1376). Kulliyat-ı Bîdil-i Dehlevî. Haz. Hüseyin Ahi. Tahran: İlham.

Elahi Ghomshei, Mehdi (1379). Nâme-i Hüseynî. Tahran: İntişarat-i Rowzaneh.

Fedai-i Mazenderani (1377). Divan. Haz. Feridun Ekber Shel Darrehi, Tahran

Feyyaz Lahici (1373). Divan. Haz: Celil Asker Nejad, Tahran: İntişarat-ı Danişgah-i Allameh Tabatabai. Forsat-i Shirazi (t.y.). Divan. Haz. Ali Zerrin Kalem. Tahran: İntişar-1 Sirus.

Homaei, Jalaluddin (1364). Divan-ı Sena. Haz: Mahduht Banu Humaei, Tahran: Neşr-i Huma. 
Homaei, Jalaluddin (1369). Makalat-i Edebi. Tahran.

Homay Shirazi (1363). Divan. Haz: Ahmed Keremi. İntişarat-1 Mah.

İbn Manzûr, Muhammed ibn Mukarram (1988). Lisânü'l-Arab. Beyrut: Dârü İhyâi't-Türâsi'l-Arabî.

Malek o-Sho'arā Bahār (1358). Divan. Tahran: Neşr-i İlm.

Meftûn-1 Hemedânî (1334). Divan. Haz: Rıza Meftun. Hemedan: Neşr-i Hemedan.

Mesrur, Hüseyin (1338). Raz-ı İlham; Divan-ı Üstad-ı Suhen Hüseyin Mesrur. Tahran: Keyhan.

Minorskiy, V. (1387). İran der Zaman-ı Nadir Şah. Tahran: Dünya-yi Kitab.

Muhaddis-i Horasani, Zehra (1388). Şiir-i Ayini ve Tesir-i İnkılab-i İslami ber An, Tahran, Mücteme-i Ferheng-i Aşura.

Muhammed-Zade, Merziye (1383). Daniş-name-i Şïr-i Aşurai: İnkılab-ı Hüseyni der Şïr-i Şairan Arap ve Acem. Tahran.

Mücahidi, Muhammed Ali (1386). Karivan-i Şiir-i Aşura. Kum: ZemZem-i Hidayet.

Neşat-ı İsfehani, Abdulvahhab (1379). Gencine - Mecmua-i Asar-i Neşat. Tahran: İntişarat-ı Şark.

Nezir-i Nişaburi, Muhammed Hüseyin (1379). Divan-ı Neziri. Haz: Muhammed Rıza Tahiri. Tahran: İntişarat-1 Nigah.

Nir Mumgani, Muhammed Taki bin Muhammed (1359). Divan-ı Ateşkede-i Huccetü'l-İslam Nir. Tebriz: Hatif.

Rafet-i Semnânî (1363). Divan. Haz. Nasrullah Nuh. Tahran: Saziman-i Neşr.

Ruhani, Visal (1319). Gülşen-i Vișâl. Tahran.

Sabâhî Bidguli, Hacı Süleyman (1338). Divan-ı Sabâhî Bidguli. Tahran.

Saghir Isfahani, Muhammed Hüseyin (1366). Musibetname. Tahran.

Sahibkari, Zebihullah (1379). Seyri der Mersiye-i Aşurai: Tahran: İntişarat-i Aşura.

Sâib -i Tebriz, Miraza Muhammed Ali (1345). Divan-ı Sâib -i Tebriz. Tahran: İntişarat-i Encümen-i Asar-1 Milli.

Samani, Oman. Gencine-i esrar. Haz: Muhammed Ali Mücahidi. Kum: İntişarat-i Usve.

Sengeri, Muhammed Ruza (1380). Negd ve Berresi-i Edebiyat-i Manzum-i Defa-i Mukaddes. Tahran: Neşr-i Palizan.

Şahrohi, Mahmud; Kaşani, Abbas Müşfik (1365). Tecellî-i Aşk der Hamasah-i Aşura. Tahran: Üsve.

Şemisa, Sîrüs (1375). Sebk Şinasi der Şiir. Tahran: Firdus.

Tefsiri, Muhammed (1376). Gencîne-i Niyakan ez Firdusi ta Şehriyar. Tahran: İntişarat-1 Majd.

Tusi, Muhammed Kazim (1368). Pertuvi ez Hayat; Mecmua i Eşar Horasan. Neşr Muhammed Kazimi Tusi.

Vahshi Bafqi, Şems el-Din Muhammed (1388). Divan-ı Vahshi Bafqi. Haz: Hüseyin Azeran. Tahran: İntişarat-ı Emir Kebir.

Visâl-i Şîrâzî (t.y.).Divan. Haz: Muhammed Abbasi. Tahran.

Yaghma-ye Jandaqi (1357). Divan. Haz: Seyydi Ali Ali-Davudi. Tahran.

Zerrînkûb, Abdulhüseyin (1363). Seyri der Şiï Farsi. Tahran. 